\title{
An Empirical Analysis of Islamic Banking (IBs) Contribution to Indonesia's Inclusive Growth'1
}

\author{
Muhammad Yusuf Ibrahim \\ Tazkia Islamic University College, Indonesia \\ Corresponding email: muhammad.ibrahim@student.tazkia.ac.id \\ Indra \\ Tazkia Islamic University College, Indonesia, indradata@gmail.com
}

Article History

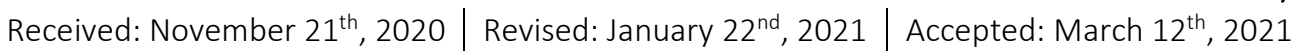

\begin{abstract}
The research is aim to attest and assess empirically the contribution of Islamic banking (IBs) on the inclusive growth in Indonesia. By taking a trial-stage method i.e. descriptive analysis to elaborate a statistical data, autoregressive distributed lag (ARDL) model to assess empirically the contribution in a long-term, and error correction model (ECM) to assess the contribution in a short-term empirically. The findings are, total deposits and total financing only contribute positively significant into GDP and gini ratio in a long-term, that similiar with the previous study. Then, a total financing contribute negatively to all indicators of inclusive growth in a long-term, but, its only significance on GDP and gini ratio. But, it was contribute significantly to all indicators in a short-term. So. The findings was only evidence the significance contribution of IBs on inclusive growth in a short-term. Based on it, a long-term contribution of IBs still cathegorized as the area that requires an extentions in order to accomplish it.
\end{abstract}

Keywords: Islamic Banking (IBs), Inclusive Growth, Poverty, Empirical Analysis JEL Classification: G18, G21, I31, 132, I38

Type of paper: Research Paper

@ IJIEF 2021 published by Universitas Muhammadiyah Yogyakarta, Indonesia All rights reserved

DOI:

Web:

https://doi.org/10.18196/ijief.v4i0.10342 https://journal.umy.ac.id/index.php/ijief/article/view/10342

Citation:

Ibrahim, M. Y., \& Indra. (2021) An empirical analysis of Islamic banking (IBs) contribution to Indonesia's inclusive growth. International Journal of Islamic Economics and Finance (IIIEF), 4(SI), 87-120. DOI: https://doi.org/10.18196/ijief.v4i0.10342.

${ }^{1}$ The research was funded by Bank Indonesia Institute through research grant fund program of Bank Indonesia 2020. 
Ibrahim \& Indra | An Empirical Analysis of Islamic Banking (IBs) Contribution to Indonesia's Inclusive Growth.

\section{Introduction}

\subsection{Background}

Islamic banking was a financial institution that operates based on Islamic principles and it has grown massively in Indonesia since 1992 (Ismal, 2010; Al Nasser \& Muhammed, 2013). By the average annual growth of assets which up to $51.11 \%$ since $2000-2010$ and its still growin up (Ascarya, 2010). Recorded in June 2020, total assets of Islamic banking in Indonesia reached Rp356.33 trillion (OJK, 2020). Means, it was increased rapidly than June 2010 which only Rp78.14 trillion or it is equal to $456.015 \%$ in the past 10 years.

With that growth, Islamic banking should has contributed to Indonesian economic improvement and growth. As in other countries and it has been proven by a several studies. ${ }^{2}$ And it was shown to has a contribution to GDP as noted in El Ayyubi, et al. (2017). However, it is not enough if the role of Islamic banking was only measured by GDP. Because the goals of Islam was not only an exclusive economy, but the inclusiveness or precisely is falah (prosperity) (Ismail \& Shaikh, 2017). So, this analysis will takes an inclusive growth as a measurement of falah. Completing a GDP which cannot illustrated an economic dynamic exhaustively (Pietak, 2014).

Inclusive growth alone, officially adopted in Indonesia at 2010. Even though, the concept was only developed in 2004 by UNDP (United Nation Development Program). And currently, it was developed by international organizations (Kusumawati, Elhorst, \& Haan, 2016). Wherein this concept, the economy is not only measure by GDP. But also measured by poverty, employment, and income distribution as formulated by world bank and IMF (Anand, Mishra, \& Peiris, 2013; Kusumawati, et al., 2016). By measuring those instruments, the ideal condition in economy could be achieved. Because it is measuring the economy broadly as stated by Suryanarayana (2013). So, the concept in line with prosperity goals. Hence, inclusive growth is compatible to be used to measure an Islamic banking contribution on economy.

Therefore, the current research will analyze the contribution of Islamic banking (IBs) due to an economic through an inclusive growth. It is considered appropriate with an Islamic goals on economics. And this research is the complementation of a previous research, Abd.Majid \& Kassim (2015). Which analyze a contribution of Islamic banking (IBs) to the country's economy, but only measured from GDP. While the current research has improved a measurement of country's economy by inclusive growth.

\footnotetext{
2 Al-Yousif (2002), Vaithilingam, et al. (2005), Habibullah \& Eng (2006), Ibrahim (2007), Cordow, et al. (2011) and Abd.Majid \& Kassim (2015).
} 
Ibrahim \& Indra | An Empirical Analysis of Islamic Banking (IBs) Contribution to Indonesia's Inclusive Growth.

Besides it, the current research is also aim to verify the statement of previous study with similiar topic, that is, Susilo (2015). Which stated that Islamic financial inclusion has no contribution to the inclusive growth in Indonesia, even thought it was not proven empirically. So, the current research will attest it empirically. But it will focus on Islamic banking (IBs) to narrow the discussion down and adapt it to the current research goals. In essence, the research will attest and assess the contribution of Islamic banking (IBs) to an inclusive growth in Indonesia through an empirical approach to accomplish a previous researchs at this topic.

\subsection{Objectives}

The purposes of the research are to enriching the analysis and literature of Islamic finance and prosperity of growth which representated by an inclusive growth in case of Indonesia. And also to attest and assess the contribution of Islamic banking (IBs) to inclusive growth. By dual specific objectives, as follows;

RO1:

Analyzing a relationship between Islamic banking (IBS) and inclusive growth based on statistical data

RO2: Attesting and assessing a contribution of Islamic banking (IBS) to an inclusive growth in Indonesia

\section{Literature Review}

The research consist of a several theoretical background which associated to a financial literature topic. Specifically, involve with an Islamic banking (IBs) and Inclusive growth theory, as follows:

\subsection{Islamic Banking (IBs) and The Indicators}

An analyzed Islamic banking (IBs) was an Indonesian Islamic banks. Then, to adjust it with an analytical goals, the indicators which will be used to measure it are total deposits and total financing of Islamic banking (IBs). Where the election of those instruments has adapted from a previous research, Abd.Majid \& Kassim (2015). Although on the research, there are five indicators, that is total deposits, total financing, Islamic stock index, inflation in term of consumer price index, and export-import. But, the research analyze the Islamic banking and financial institutions (IBFIs). So, it was using five indicators to measure it. While, the current research was only focus to analyze the Islamic banking (IBs). So, the indicators which will be used at this analysis was only two, that is total deposits and total financing. And the election of the indicators has been reviewed be based on a several previous study. 
Ibrahim \& Indra | An Empirical Analysis of Islamic Banking (IBs) Contribution to Indonesia's Inclusive Growth.

Such as total deposits which was reinforced by Ayuniyyah, et al., (2013) and Zirek, et al., (2016) as an indicator of Islamic banking (IBs). Then also for a compability of total financing as the other indicator of Islamic banking (IBs) as proven in Dhaoui (2018). So, based on that reinforcement, it can be assumed that the instrument has compable to be an Islamic banking (IBs) indicators at this analysis. Furthermore, the research is not only presents an evidence of a compability of those indicators. But, it also provide a rationale of the elemination of the other indicators, apart from differences in research object.

The rationale of an indicators elimination rfom a previous research was based on t he statement of a several study. As stated in Ayuniyyah, et al., (2013) that export-import and inflation has no correlation with Islamic banking (IBs). Then, for an Islamic stock market, although, it was proven that Islamic stock market has a correlation with Islamic banking (IBs), but when the instrument included as an indicator at this analysis. A discussion will not focus on Islamic banking (IBs) to the inclusive growth. So, to narrow down an analysis into Islamic banking (IBs). Then, the instruments will not included in the analysis. And by the indicators election and elimination, the research will be more efficient and appropriate with an objectives of a research.

\subsection{Inclusive Growth and The Indicators}

Inclusive growth is an ideal wealth management concept which can measure an economy exhaustively (Lee, 2018). It is also called by shared growth, broad-based growth, or pro-poor growth (Suryanarayana, 2013). The concept was discussed by an international organizations and policy makers. But it was first developed by United Nations Development Program (UNDP) in 2004, and adopted by Indonesia in 2010 (Kusumawati, et al., 2016).

As an introduction, it will be briefly explained about inclusive growth. Felipe (2012) defines an inclusive growth as an ideal condition that can be achieved when all of society participate and contribute together. And the statement was similar with Anand, et al. (2013) which stated the inclusive growth uses all economic instruments to achieved it. Means, it is measure an economy exhaustively. And the overview of the concept has suggested by a several international organizations. Even though, there are still a disagreement of a measurement indicators of it. But a several instrument was planned as an indicators by an international organizations, as listed on a Table 1. 
Ibrahim \& Indra | An Empirical Analysis of Islamic Banking (IBs) Contribution to Indonesia's Inclusive Growth.

Table 1. Inclusive Growth Indicators

\begin{tabular}{|c|c|}
\hline $\begin{array}{l}\text { International } \\
\text { Organizations }\end{array}$ & Indicators \\
\hline & - Economic Growth \\
\hline World Bank & - Poverty \\
\hline & - Employment \\
\hline & - Economic Growth \\
\hline ADB & $\begin{array}{l}\text { - Equal Opportunity } \\
\text { - Broader Access for Participate }\end{array}$ \\
\hline & - Stange Social Safety Nets \\
\hline IMF & \\
\hline EU Commission & $\begin{array}{l}\text { - Economic Growth } \\
\text { - Employment } \\
\text { - Education } \\
\text { - Poverty }\end{array}$ \\
\hline UNDP & $\begin{array}{l}\text { - Economic Growth } \\
\text { - Equality on Income Distribution } \\
\text { - Opportunity to Participate and have } \\
\text { Benefir from Growth }\end{array}$ \\
\hline OECD & $\begin{array}{l}\text { - Economic Growth } \\
\text { - Household Income } \\
\text { - Health Status } \\
\text { - Jobs }\end{array}$ \\
\hline
\end{tabular}

Based on table 1, there are plenty indicators which has proposed by different organizations. But, this analysis will uses an indicators for an inclusive growth which consider to world bank and IMF proposal. The election of the indicators with world bank and IMF proposal basis was because of an analytical topic. Where the research is about a financial literature, so, the reference that considered appropriate to be used at this analysis is a financial institutions or organizations. Therefore, the indicators of inclusive growth at this analysis are economic growth, poverty, employment, and income distribution. And each indicators has its own measurement.

At this analysis, the instrument which will be used to measure an economic growth is GDP. It is because GDP has been agreed internationally as a tool as measurement of an economic growth (Wesselink, et al., 2007; Haller, 2012; Edeme, 2018) Then, poverty indicators will be representated by a poverty rate. Because, it has been a standard to measure a poverty (Eberstadt, 2008). Apart from being a standard, a poverty rate was also proven illustrates the growth on income side (Akinbobola \& Saibu, 2004). And the other indicator of inclusive growth is employment, which will be measured by unemployment rate. Then, the last indicator is an income distribution which basically intend to measure an inequality. So, the gini ratio will be used to 
Ibrahim \& Indra | An Empirical Analysis of Islamic Banking (IBs) Contribution to Indonesia's Inclusive Growth.

measure it (Catalano, et al., 2009). Where the compability of those instrument has been reinforced by a several research, that is Farris (2010), Brauninger (2002) and Onodugo, et al. (2017).

\subsection{Previous Research}

The research was adapted and developed from Abd.Majid \& Kassim (2015), which analyze the contribution of Islamic banking and financial institutions (IBFIs) on economic growth. But, the research was only use GDP as a sole indicator of growth. Even though, its not enough to measure an economic exhaustively (Pietak, 2014; Ivkovic, 2016). Therefore, an inclusive growth has been selected as an indicators to measure an economic condition at this analysis.

Besides it, there are several research which discuss a similiar topic with current research. That is, Doumbia (2008), which analyze the inclusive growth on good governance side. Lee (2008), although the study was only a qualitative research which use a descriptive analysis and literature method. Then Sengupta (2010) which states that inclusive growth was a solution to measure the economy in detail to equality problem. And the other research is Suryanarayana (2013) which analyze the inclusive growth in term of the wealth distribution, including a banking sector as a medium of distribution. But, the research was only uses a descriptive analysis. Means, the study was non-empirical analysis.

So as with the research of Susilo (2015) which analyze the effect of Islamic financial institution in alleviating a poverty. And states that Islamic financial inclusion (including Islamic banking) has no effect on poverty alleviation which is a part of inclusive growth But the statement still does not evidence empirically. Because the resaerch only use a literature study and a descriptive analysis. So, the current analysis is prepared to analyze the statement and evidence it empirically.

\subsection{Conceptual Framework}

The Following is a conceptual framework which has arranged based on Polancic (2008) model. The framework contain an analyzed variables, indicators, measurement and methodology. 
Ibrahim \& Indra | An Empirical Analysis of Islamic Banking (IBs) Contribution to Indonesia's Inclusive Growth.

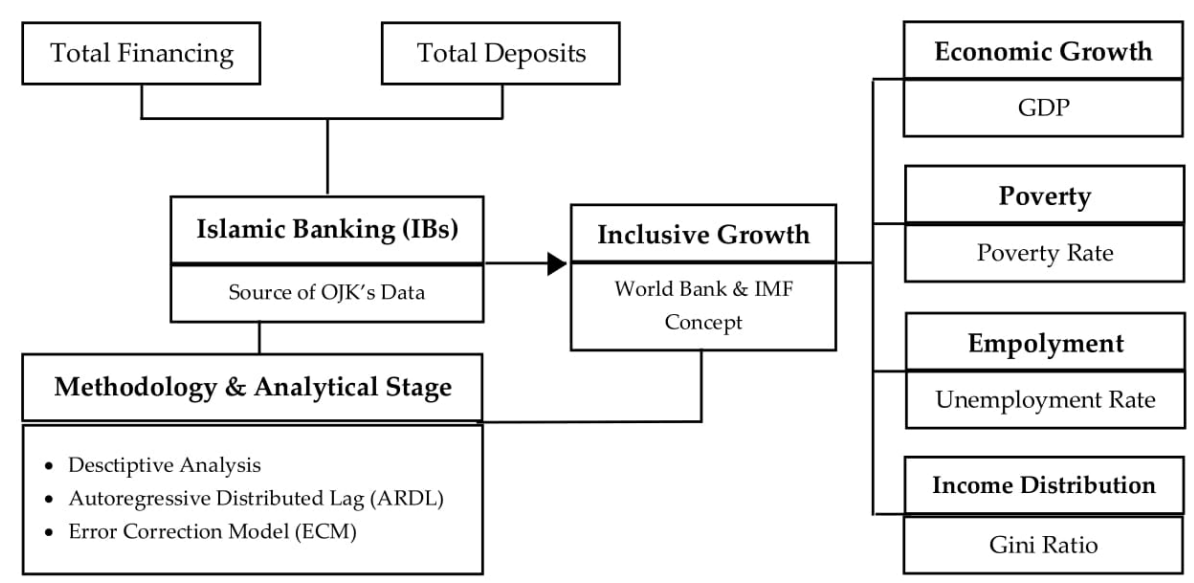

Figure 1. Conceptual Framework of Research

The research analyze the Islamic banking contribution to inclusive growth. Where, both of variables has its own indicators. Where Islamic banking explained by total deposits and total financing. While, the indicators of inclusive growth consist of GDP, poverty rate, unemployment rate, and gini ratio. Where the selection of the Islamic banking indicators refer to Abd.Majid \& Kassim (2015) with some modification (election and elimination of indicators). And the inclusive growth indicators was quoted from world bank and IMF model proposal, and it is reinforced by Anand, et al. (2013), Kusumawati, et al., (2016) and Muhammad \& David (2019) as a theoritical background.

\section{Methodology}

\subsection{Research Data}

The research will analyze the contribution of Islamic banking (IBs) on inclusive growth. So, a variable that will be analyzed are total deposits and total financing as an indicators of Islamic banking (IBs). And use a GDP, poverty rate, unemployment rate, and gini ratio as an indicators of inclusive growth. That Whose the data has been collected from reliable sources.

Where the data of total deposits and financing of Islamic banking has been collected from OJK's (financial services authority of Indonesia) website. While, a data of inclusive growth indicators has collected from the website of ministry of trade of Indonesia and central bureau of statistics Indonesia. Which arranged in time series form, starting from 2010 to 2019. But, a collected data still in annual, semiannual, or quarterly. So, in order to balance a data and facilitate an analysis, the data was interpolated into a mothly data based on polynomial approach. Its aim to estimate an intermediate value between a predertemined data points (Jia, 2017). But for 
Ibrahim \& Indra | An Empirical Analysis of Islamic Banking (IBs) Contribution to Indonesia's Inclusive Growth.

a data of GDP which appled manufacture production index as a proxy of that instrument. And balancing an analyzed time series data in the same time interval measure.

\subsection{Indicators Description}

Indicator description is described in table 2

Table 2. Indicators Description

\begin{tabular}{cl}
\hline Variable & \multicolumn{1}{c}{ Deposits } \\
\hline Indicators & \multicolumn{1}{c}{ Islamic } \\
\hline & For a bank, deposits was a key tools of \\
& a financing project. Which in practice \\
& is used as a financing capital by a bank \\
& (Onyema \& Odeiem-Ogulu, 2019). \\
& And, in Islamic banking (IBs), deposits \\
& was divided into four scheme, that is \\
& wadi'ah (save keeping) deposit, \\
& mudharabah (profit sharing) deposit, \\
Descriptions & tawarruq (benevolent) deposit, and \\
& qard (cost plus save) deposit (Aris, et \\
& al., 2013).
\end{tabular}

Financing

Financing is a provision of funds for a business project agreed by two parties. It causes one party to have obligations to the other for a certain period (Kasmir, 2005). And also can be applied personally or without institutional bacground (Rivai \& Arifin, 2010). Where in Islamic banking (IBs), the it has been devided of two type based on the segment.

Based on consumer segment, a financing was consist of four product. That is, house financing, personal financing, vehicle financing, and staff financing. Then, about a financing which based on corporate segment are consist of, trade financing, asset-based financing, and corporate investment (Aris, et al., 2013).

\begin{tabular}{|c|c|c|}
\hline Variable & \multicolumn{2}{|c|}{ Inclusive Growth } \\
\hline Indicators & Economic Growth & Poverty \\
\hline Measurement & GDP & Poverty Rate \\
\hline Descriptions & $\begin{array}{l}\text { Economic growth was a complex } \\
\text { phenomenon of a country that } \\
\text { monitored from population, } \\
\text { resources, infrastructure, and the } \\
\text { management of government (Haller, } \\
\text { 2012). And its usually measured by } \\
\text { GDP, as a measure that has been } \\
\text { recognized internationally (Edeme, } \\
\text { 2018). }\end{array}$ & $\begin{array}{l}\text { A poverty can be defined as a deficiency in } \\
\text { wealh distribution by a government into a } \\
\text { household. And the limitation of } \\
\text { household's basic needs fulfillment } \\
\text { (Mowafi \& Khawaja, 2005). A poverty rate } \\
\text { will be used to measure it (Goedhart, et } \\
\text { al., 1977). And in Indonesia alone, a } \\
\text { poverty line was measured based on basic } \\
\text { needs approach (BPS, 2020). }\end{array}$ \\
\hline Indicators & Employment & Income Distribution \\
\hline Measurement & Unemployment Rate & Gini Ratio \\
\hline Descriptions & $\begin{array}{l}\text { The waste of resources which leads to } \\
\text { a reduction in the prospect for a long- } \\
\text { run growth and reduces a welfare of a } \\
\text { country. Thus causing an expansion of } \\
\text { fiscal costs for the government } \\
\text { (Chowdhury \& Zuk, 2018). Therefore, } \\
\text { the government takes a measure to } \\
\text { monitor unemployment in its } \\
\text { territory. And use the unemployment } \\
\text { rate as agreed by international } \\
\text { organizations and the majority of } \\
\text { countries (ILO, 2015). }\end{array}$ & $\begin{array}{l}\text { Income distribution was an important } \\
\text { instrument that influences a people's } \\
\text { cohesion and iy also determines an } \\
\text { inequality. When an income doesn't } \\
\text { distribute equally, so, an inequality will be } \\
\text { exist in a society (Stewart, 2000). } \\
\text { Therefore, gini ratio will be used to } \\
\text { measure it. Because, a gini ratio was an } \\
\text { index which works to measure an equality } \\
\text { of wealth distribution of a country. And } \\
\text { served in statistical summary (Farris, } \\
\text { 2010). }\end{array}$ \\
\hline
\end{tabular}


Ibrahim \& Indra | An Empirical Analysis of Islamic Banking (IBs) Contribution to Indonesia's Inclusive Growth.

\subsection{Model Development}

This research is an adaptation and development of Abd.Majid \& Kassim's (2015) research. By taking a similar topic, but narrowed it down to Islamic banking (IBs). While Abd.Majid \& Kassim's (2015) was analyze an Islamic financial literature in a broader discussion, that is, Islamic banking and financial institutions (IBFIs). And another difference lies in a research geographical bondaries. Where a previous research takes Malaysia as a geographical bondaries, but, the current research takes Indonesia of its case.

Furthermore, there is a difference of an analytical object. Where it doesn't analyze the economic growth, but substitute it into inclusive growth as a measure of country's economic. It is intended as an improvement of a previous research. Because after a review, an economic growth was inappropriate to measure an economy based on Islamic economic goals. So, an inclusive growth has been selected as a measure of economy because it is in line with Islamic economic goals. And based on the reasonings, the research has been complied. With the aim, to analyze the contribution of Islamic banking as like as previous research, but on different object, that is, inclusive growth.

\subsection{Method}

In line with $R O$ (research objectives), this research will use a mixed method. By combining a descriptive analysis methods as an application of qualitative approach. Then, an autoregressive distributed lag (ARDL) and error correction model (ECM) model as a tools of quantitative analysis. Means, the analysis use quad-stage method model. The first method i.e. descriptive analysis, works to answer RO1 of the research. Then, ARDL and ECM will be used to answer RO2. But, before applying it, the methods will be briefly explained, as follows;

\subsubsection{Descriptive Analysis}

Theoritically, descriptive analysis was a method which is used to describe a phenomenon of a research. And it was the most used in a research (Adams, Khan, \& Raeside, 2007). Where the use is intended to elaborate a statistical data and composing an analytical assumption. And the data will be served in a substative form (Hart, 1998; Ibrahim, et al., 2019). Consider to this explanation, the method is appropriate to use in answering $R O 1$.

\subsubsection{Autoregressive Distributed Lag (ARDL) Model}

Autoregressive distributed lag model or referred to as ARDL, was a method introduced by Pesaran \& Shin (1995) (Hamzah \& Handri, 2017), that is used 
Ibrahim \& Indra | An Empirical Analysis of Islamic Banking (IBs) Contribution to Indonesia's Inclusive Growth.

in a single equation of dynamic regression. And it has a work to analyze a time series data in a long-term econometrical approach (Hassler \& Wolters, 2005). It was a method which compatible to estimate a co-integration of variables. It can capture a dynamic relationship of variables by the existence of lag. So, it will cause a flexibility on a different lag of variables in endogenous and exogenous variables. The model can also analyze the effect of exogenous variables on each lag in different time intervals (Zaretta \& Yovita, 2019).

The method is applied to answer RO2, i.e. to attest and assess the contribution of Islamic banking (IBs) to inclusive growth. Therefore, its required an empirical method such as ARDL to answer it. But the use of ARDL was only ro evidence the contribution of analyzed variables in a longterm.

\subsubsection{Error Correction Model (ECM)}

Error correction model (ECM) at this analysis has a work to accomplish an ARDL method in asnwer RO2. Where application of ECM will streghtening the result of ARDL in answering RO2. ECM firstly introduced by Dennis Sargan in 1950, then popularized by Eangle-Granger (1987) (Alogoskoufis, 1991). And defined as a method which has a function to adjust an instrument and mantain it, in order to make a research get near to its desired result (Phillips, 1957). Which in practice, ECM imposes a linier homogenity of researched variables (Pagan, 1985). So, the method will accomplish ARDL method. That in this analysis, ECM will use to assess the cointegration of variables in a short-term. Such as in (Tulak, Junaidi, \& Utami, 2017).

\subsection{Model Specification}

As explained above, the research will use ARDL and ECM to answer an empirical analysis of RO2. So, the formulation or model specification of the models is required. Therefore, this research has been provide it.

The first is ARDL model. But the research formulated the model based on Varquez et al. (2012). Its because a traditional model is considered inapplicable anymore. So, it requires an alternative model which can estimate an hypothetical procudure maximally (Johansen, 1992). Therefore, a developed model of ARDL by Varquez et al. (2012) has been selected to formulate a research hypothesis of ARDL at this research. And the following are the model; 
Ibrahim \& Indra | An Empirical Analysis of Islamic Banking (IBs) Contribution to Indonesia's Inclusive Growth.

$$
\begin{aligned}
& L I N C^{i, t}=\propto+\sum_{j=1}^{p 1} \beta i, j L G D P_{i=t, j}+\sum_{j=2}^{p 2} \beta i, j L P R_{i=t, j}+\sum_{j=3}^{p 3} \beta i, j L U R_{i=t, j}+ \\
& \sum_{j=4}^{p 4} \beta i, j L G R_{i=t, j}+\sum_{j=0}^{q 1} \varnothing 1 j \operatorname{lnT} D_{t-j}+\sum_{j=0}^{q 2} \varnothing 2 j \operatorname{lnTF} F_{t-j} \ldots \text { (1) } \\
& L G D P^{i, t}=\propto+\sum_{j=1}^{p 1} \beta i, j L G D P_{i=t, j}+\sum_{j=0}^{q 1} \varnothing 1 j \ln T D_{t-j}+\sum_{j=0}^{q 2} \varnothing 2 j \ln T F_{t-j} \ldots \text { (2) } \\
& L P R^{i, t}=\propto+\sum_{j=1}^{p 2} \beta i, j L P R_{i=t, j}+\sum_{j=0}^{q 1} \emptyset 1 j \ln T D_{t-j}+\sum_{j=0}^{q 2} \varnothing 2 j \ln T F_{t-j} \ldots \text { (3) } \\
& L U R^{i, t}=\propto+\sum_{j=1}^{p 3} \beta i, j L U R_{i=t, j}+\sum_{j=0}^{q 1} \varnothing 1 j \operatorname{lnT} D_{t-j}+\sum_{j=0}^{q 2} \varnothing 2 j \operatorname{lnTF} F_{t-j} \ldots \text { (4) } \\
& L G R^{i, t}=\propto+\sum_{j=1}^{p 4} \beta i, j L G R_{i=t, j}+\sum_{j=0}^{q 1} \varnothing 1 j \ln T D_{t-j}+\sum_{j=0}^{q 2} \varnothing 2 j \ln T F_{t-j} \ldots \text { (5) }
\end{aligned}
$$

Where;

LINC $_{i . t}=$ Natural Logarithm of Inclusive Growth as measured by GDP, poverty rate, unemployment rate, and ginir ratio $L I N C_{i, t}=$ $\ln \left[\frac{I N C_{i, t}}{1-I N C_{i, t}}\right]$

$L G D P_{i . t-j}=$ Natural Logarithm of GDP

$L P R_{i . t-j}=$ Natural Logarithm of Poverty Rate

$L U R_{i . t-j} \quad=\quad$ Natural Logarithm of Unemployment Rate

$L G R_{i . t-j}=$ Natural Logarithm of Gini Ratio

$\operatorname{lnT} D_{t-j} \quad=\quad$ Natural Logarithm of Total Deposits of Islamic Banking

$\operatorname{lnTF_{t-j}} \quad=\quad$ Natural Logarithm of Total Financing of Islamic Banking

Then, the cointegration of each exogenous variables would be determined in a long term and short term, and the representative variables of inclusive growth added up by the value of estimation coefficient $\left(\emptyset_{i}\right)$ of each the exogenous variables. Then the chain rules would be used to determine the cointegration of the shock of each exogenous variables due to untransformed GDP, poverty rate, unemployment rate, and gini ratio which would be evaluated by the sample of inclusive growth's average. Then, after an ARDL estimation, the model will be estimate by ECM method with a model specification as follows;

Short term effect;

$\frac{\Delta I N C_{i}}{\Delta X_{i n c}}=I N C_{i} x\left(1-\overline{I N C}_{i}\right) \times \sum_{q i n c} \emptyset_{k, t-j} \ldots(6)$

Where;

$\left(\emptyset_{i}\right)=$ Estimated value of exogenous variables coefficient

$X_{i n c}=$ Way of exogenous variables cointegrate inclusive growth

$I N C=$ Endogenous Variables; Inclusive growth

By following elaboration, that is,,$X_{\text {inc }}$ means, how the exogenous variables (Islamic banking (IBs) variable and its indicators) cointegrate INC (Inclusive Growth variable and its indicators) which classified in the average of the average of inclusive growth to $i$ in observation. 
Ibrahim \& Indra | An Empirical Analysis of Islamic Banking (IBs) Contribution to Indonesia's Inclusive Growth.

\subsection{Stage of Analysis}

Regarding to the explanation above, the research uses mixed method which consist of trial-stage method model. By the following stages sequence;

1) Descriptive analysis that works to elaborate a statistical data and composing an analytical assumption. And to answer RO1.

2) Unit root test, to seek a constancity of data's mean and variant of each lags (Gujarati, 2003). And it will be tested based on Augmented Dickey Fuller (ADF) test and the automatic lag will be selected by Schwartz Information Criterion (SIC) approach.

3) Lag determination, an important stage to seek the best model of ARDL (Bahmani-Oskooee \& Bohl, 2000). The test will apply F-bound test of ARDL long bound testing.

4) Breusch-Godfrey serial correlation LM Test, to ensure that there are no violations of econometric principles by the selected model and test the suitability of the model that has been selected to be estimated at a later stage.

5) Autoregressive distributed lag (ARDL) model test, to attest and assess the cointegration between Islamic banking (IBs) and inclusive growth in a long-term. (To answer RO2)

6) Error correction model (ECM), to attest and assess the cointegration between Islamic banking (IBs) and inclusive growth in a short-term. (To answer RO2) 
Ibrahim \& Indra | An Empirical Analysis of Islamic Banking (IBs) Contribution to Indonesia's Inclusive Growth.

\section{Results and Analysis}

\subsection{Statistical Description}
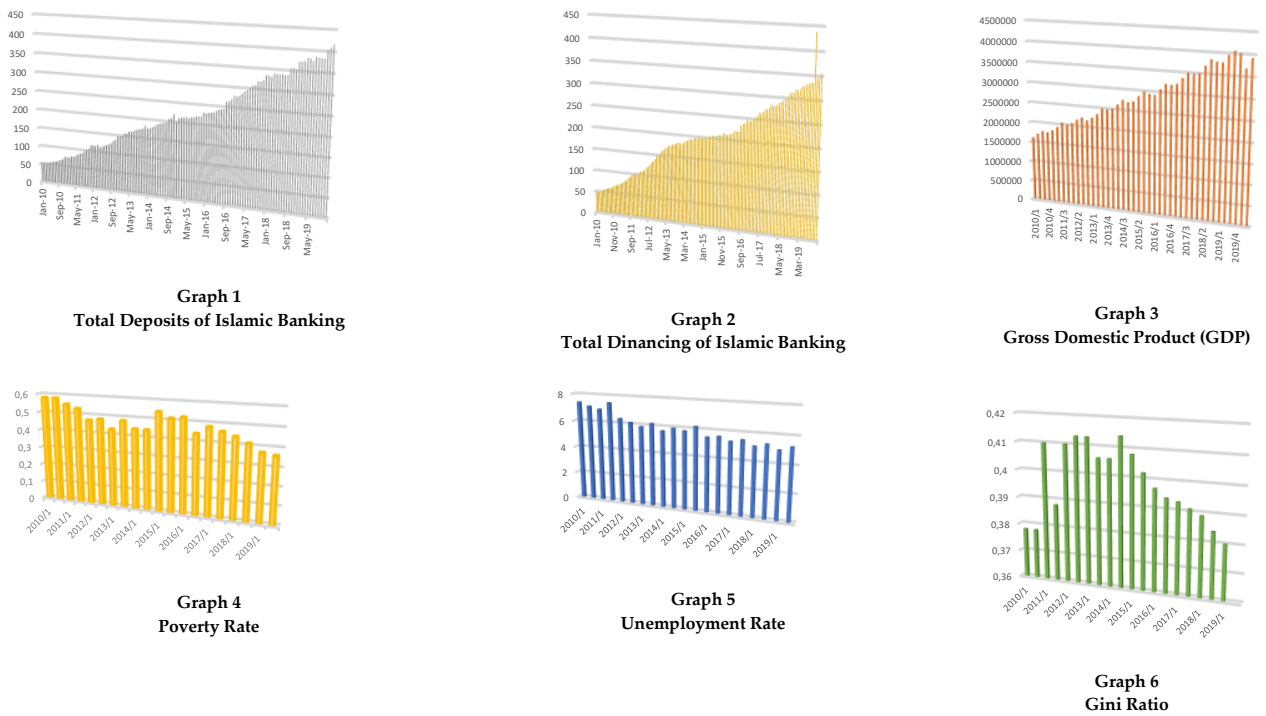

Figure 2. Graphics of Research Data

Source: OJK's website and processed by researcher

Figure 2 shows a statistical condition of the data. Where a graph 1 and graph 2 represent the growth of total deposits and total financing of Islamic banking (IBs). And statistically, the graph shows an excellent growth of IBs indicators. That is, the growth are progressive with percentage of growth of $180.2 \%$ in total deposits and $166,8 \%$ in total financing since December 2015 to December 2019.

As it increases, a data of GDP is also show a fairly steady inrease as presented on a graph 3 . Which of the same time interval, GDP has increase of $136.7 \%$. With annual growth average of $108,4 \%$ since $2015 .{ }^{3}$ But, the other indicators has a contrary trend of the growth. Where the trend is a decrease, as shown in graph 4, 5, and 6. Although, a graph 6 as an illustration of gini ratio condition has a volatile decrease. But overall, gini ratio decreased steadly sence 2015. As like as poverty rate and unemployment rate that was shown by graph 4 and graph $5 .{ }^{4}$

Based on those explanation, it can be concluded that a data of IBs indicators increases as like as GDP. Along with it, a poverty rate, unemployment rate, and gini ratio has decreased. So, the movement of data in the graph shows a relationships that can be an assumption of the research. And those statistical data indicate a several assumption of the analysis, that is; Islamic banking

\footnotetext{
${ }^{3}$ Data sourced from Ministry of Trade website and processed by researcher

${ }^{4}$ Data sourced from Central Bureau of statistics.
} 
Ibrahim \& Indra | An Empirical Analysis of Islamic Banking (IBs) Contribution to Indonesia's Inclusive Growth.

(IBs) has a positive relation with GDP. And vice versa on poverty rate, unemployment rate, and gini ratio. But, the assumption doesn't valid yet. And it requires an evidence by an empirical analysis. So, to clarify the assumption, this research will analyze the relations of those variables empirically. And the analysis will applied triple-stage model of empirical method, that is, ARDL and ECM as stated in a further discussion.

\subsection{Econometrical Result}

This econometrical estimation is aim to asnwer $\mathrm{RO} 2$ by estimate the model specifications, which consist of ARDL and ECM models. But before it, there are a several testing prerequisites that need to be met. Firstly, it is started from stationary test by unit root test. The test works to determine whether the data are stationary or should be differenced to render it (Hatanaka, 1995). Where in this analysis, this estimation is applied augmented DickeyFuller (ADF) test by Schwartz information criterion (SIC). Augmented DickeyFuller (ADF) test estimates the hypothesis of time series data in against the alternatives (I(0) to I(1)) (Said \& Dickey, 1984; Elliot, et al., 1996). And SIC has selected because SIC is the best approach to reflect a consistency of ARDL model (Pesaran \& Shin, 1995).

Table 3. Unit Root Test

\begin{tabular}{ccccccc}
\hline Level & LNTD & LNTF & LNGDP & LNPR & LNUR & LNGR \\
\hline ADF Test Statistic & -3.914 & -5.265 & 11.208 & -1.687 & -1.347 & -0.851 \\
1st difference & LNTD & LNTF & LNGDP & LNPR & LNUR & LNGR \\
ADF Test Statistic & -4.472 & -15.478 & -7.314 & -2.382 & -7.286 & -1.776 \\
2nd difference & LNTD & LNTF & LNGDP & LNPR & LNUR & LNGR \\
ADF Test Statistic & -7.936 & -8.617 & -10.189 & -10.489 & -7.718 & -9.854 \\
& 1\% level & & & -3.486551 & \\
Test Critical Value & 5\% level & & & -2.886074 & \\
& 10\% level & & & -2.579931 & \\
\hline
\end{tabular}

Table 3 show that the variables has a unit root at level and 1st difference. So, it is requires the other differentiation of a stanionary test. It is causing the election of 2 nd difference of stationarity. And the finding show that the data become stationary of 2 nd difference. It is shown by ADF test statistic value which < test critical value of all level significantions (Elliot, et al., 1996). Means, the data has met the requirement to estimate by ARDL and ECM (Alogoskoufis, 1991; Pesaran \& Shin, 1995). After finds the stationarity, then, the lag testing by F-bound test will be applied to seek a best model of ARDL. The following are the results; 
Ibrahim \& Indra | An Empirical Analysis of Islamic Banking (IBs) Contribution to Indonesia's Inclusive Growth.

Table 4. Lag Determination

\begin{tabular}{|c|c|c|c|c|c|c|c|}
\hline \multirow{2}{*}{ Signif. } & 1(0) & I(1) & \multirow{2}{*}{ Lag Length } & \multicolumn{4}{|c|}{ Computed F-Statistics } \\
\hline & Asymptotic & $=1000$ & & LNGDP & LNPR & LNUR & LNGR \\
\hline $10 \%$ & 2.63 & 3.35 & $1(1,1,1)$ & 14.98285 & 3.726793 & 2.093083 & 6.924682 \\
\hline $5 \%$ & 3.1 & 3.87 & $2(2.2,2)$ & 7.478574 & 2.140897 & 3.416080 & 4.449665 \\
\hline $2,50 \%$ & 3.55 & 4.38 & $3(3,3,3)$ & 4.904855 & 1.918977 & 4.757787 & 3.364842 \\
\hline $1 \%$ & 4.13 & 5 & $4(4,4,4)$ & 5.377741 & 1.932132 & 5.827458 & 3.203494 \\
\hline
\end{tabular}

Consider to table 4 , it can be known that the findings are varies on a significance levels. But majority of model are significant on lag lenght 3. In detail, LNGDP was significance on lag lenght 3 in $1 \%$ level significance. LNPR was significance on lag lenght 1 with 2,5\% and 5\% level significance. LNUR was significance of lag lenghts 2 and 3 on all significance levels but $10 \%$. And the last model is LNGR, that significance on all lag lenghts but 1 , in $1 \%$ and $5 \%$ levels significance. So, based on it, the lag lenght 1 and 3 has been selected to estimate the equation (1), that was divided into 4 equation models (2, 3, 4, and 5). Because, the lag lenght was the highest significance model of F-Statistics. Which specifically, lag lenght 3 was used to estimate an model 2, 4, and 5. While, the lag lenght 1 is works to estimate an equation model 3.

When the hughest significance of lag lenghts has been found, the estimation will be continued to long run co-integration test by ARDL. But to ensure the result, the autocorrelation test is required. So, at this stage, Breush-Godfrey serial correlation LM test. it is aim to ensure that there are no violations of econometric principles by the selected model and test the suitability of the model that has been selected to be estimated at a later stage. In short, it is used to seek the autocorrelation problem of a data. The result is described on Table 5.

Table 5. Breush-Godfrey serial correlation LM test

\begin{tabular}{|c|c|}
\hline LNGDP & LNPR \\
\hline $\begin{array}{l}\text { Breusch-Godfrey Serial Correlation LM } \\
\text { Test: }\end{array}$ & $\begin{array}{l}\text { Breusch-Godfrey Serial } \\
\text { Correlation LM Test: }\end{array}$ \\
\hline $\begin{array}{lll}\text { F- } & \\
\text { statistic 2.260935 } & \text { Prob. F(3,102) } 0.0859 \\
\text { Obs*R- } & \text { Prob. Chi- } \\
\text { squared7.295163Square(3) } & 0.0631\end{array}$ & 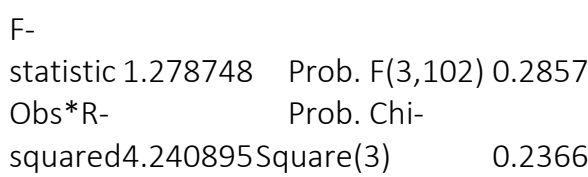 \\
\hline LNUR & LNGR \\
\hline $\begin{array}{l}\text { Breusch-Godfrey Serial } \\
\text { Correlation LM Test: }\end{array}$ & $\begin{array}{l}\text { Breusch-Godfrey Serial } \\
\text { Correlation LM Test: }\end{array}$ \\
\hline $\begin{array}{ll}\text { F- } & \\
\text { statistic } 0.775215 & \text { Prob. F(3,102) } 0.5105 \\
\text { Obs*R- } & \text { Prob. Chi- } \\
\text { squared2.608185Square(3) } & 0.4561\end{array}$ & $\begin{array}{l}\text { F- } \quad \text { Prob. } \\
\text { statistic 0.771925F(3,102) } \\
\text { Obs*R- } \quad \text { Prob. Chi- } \\
\text { squared2.597362Square(3) }\end{array}$ \\
\hline
\end{tabular}

International Journal of Islamic Economics and Finance (IJIEF), 4(SI), 87-120|101 
Ibrahim \& Indra | An Empirical Analysis of Islamic Banking (IBs) Contribution to Indonesia's Inclusive Growth.

Table 6. Long-Run Form of ARDL model

\begin{tabular}{lrcrcrcrc}
\hline & \multicolumn{2}{c}{ LNGDP $(3,3,3)$} & \multicolumn{2}{c}{$\operatorname{LNPR}(1,1,1)$} & \multicolumn{2}{c}{$\operatorname{LNUR}(3,3,3)$} & \multicolumn{2}{c}{$\operatorname{LNGR}(3,3,3)$} \\
\cline { 2 - 9 } & Coefficient & Prob & Coefficient & Prob & Coefficient & Prob & Coefficient & Prob \\
\hline LNTD & 1.208674 & 0.0000 & -26.76932 & 0.8646 & -0.086862 & 0.4785 & -0.307593 & 0.0014 \\
LNTF & -0.821624 & 0.0000 & 28.27025 & 0.8646 & -0.128297 & 0.3243 & 0.298745 & 0.0036 \\
C & 5.870713 & 0.0000 & -7.622406 & 0.8646 & 0.097103 & 0.0000 & -0.861864 & 0.0000 \\
\hline
\end{tabular}

Table 7. Error Correction Model Test Result

\begin{tabular}{crrrr}
\hline & $\operatorname{LNGDP}(3,3,3)$ & $\operatorname{LNPR}(1,1,1)$ & \multicolumn{1}{c}{$\operatorname{LNUR}(3,3,3)$} & \multicolumn{1}{c}{$\operatorname{LNGR}(3,3,3)$} \\
\hline CointEq(-1) & -0.069720 & -0.002629 & -0.124950 & -0.044565 \\
Prob & 0.0000 & 0.0002 & 0.0000 & 0.0003 \\
\hline
\end{tabular}

The result of Breush-Godfrey serial correlation LM test indicates that the data has no autocorrelation because the value of prob.chi-square > test critical value of $5 \%$. Therefore, the requirements for ARDL test has been met. The analysis can be continued to the ARDL test stage. The result is described on Table 6.

Based on table 6 , it was found that LNTD and LNTF has a significant cointegration to $\operatorname{LNGDP}(3,3,3)$ and $\operatorname{LNGR}(3,3,3)$ in a long-term, but not to $\operatorname{LNPR}(1,1,1)$ and $\operatorname{LNUR}(3,3,3)$. With the following specifications; LNTD has a positive cointegration to LNGDP, LNPR, and LNGR, but vice versa on LNUR. Then, LNTF has a negative cointegration to all of models (LNGDP, LNPR, LNUR, LNGR) in a long-run. Then, to find the short-run cointegration which has been formulated in equation model (6). And the models will be estimated by error correction model. The ECM result estimation has served in Table 7.

Previously, the long-term cointegration has been interpreted by ARDL model. So, at this analysis, the short-term cointegration will be interpreted by ECM as served in table 7. The findings shows there is a significant short-term cointegration of variables. Interpreted by CointEq(-1) and Prob value that $<$ critical value of $5 \%$. Based on the result, it can be concluded that LNTD and LNTF cointegrate significantly to $\operatorname{LNGDP}(3.3 .3), \operatorname{LNPR}(1,1,1), \operatorname{LNUR}(3,3,3)$, and LNGE $(3,3,3)$ in a short-term. Then the findings will be reinforced by a robust test as a last stage of this empirical analysis.

\subsection{Analysis}

The findings shows the relationship of variables by a several specifications. That are, the relationship that provide the contribution of Islamic banking (IBs) indicators to an inclusive growth indicators. Where in a long-term, total deposits of Islamic banking has a positive contribution to GDP, poverty rate, and gini ratio. And contribute negatively to unemployment rate. While, total 
Ibrahim \& Indra | An Empirical Analysis of Islamic Banking (IBs) Contribution to Indonesia's Inclusive Growth.

financing of Islamic banking (IBs) contribute negatively into all of inclusive growth indicators. But those indicators was only significant on GDP and gini ratio as represented in table 6 above.

Then, table 7 has served the result of the Islamic banking (IBs) contribution to an inclusive growth indicators in a short-term. And the findings evidence that Islamic banking (IBs) has contribute significantly on an inclusive growth in a short-term. It is led the raise of GDP, the decrease of poverty rate and gini ratio by the Islamic financing of IBS, and the decline of unemployment rate when a total deposits and financing of IBs increase. Means, IBs was contribute significantly in achieve the goals of inclusive growth. And it was parallel with a research assumption of statistical description, but only in a short-term.

While in a long-term, the increase of total deposits of IBs causes the GDP increase. But it also causes the increase of poverty rate and gini ratio. Even though, IBs's total deposits decreases an unemployment rate. Then, a poverty rate, unemployment rate, and gini ratio will decrease when total financing of IBs increase. But it is only significance on gini ratio in a long-term relationship. So, in a long-term case, it can be concluded that Islamic banking indicators was only contribute significantly to GDP and gini ratio, and not to the other inclusive growth indicators. Means, the statements was answered the RO2, but it can't fulfill the assumption of statistical description of the research.

\section{Conclusion and Recommendation}

\subsection{Conclusion}

The research empirically explores the contribution of Islamic banking (IBs) to an inclusive growth in a long-term and short-term. By taking a case on Indonesia since 2010 to 2019. The analysis applies a trial-stage method to answer the objectives. The methods are a descriptive analysis to describe a statistical data, ARDL to answer the contribution in a long-term, and ECM to answer the contribution in a short-term. Based on those methods, the research finds a robust conclusion.

The conclusion is, a total deposits has a significant positive contribution on gini ratio in a long-term. An increase of poverty caused by an increase of total deposits can be assumed as wealth accumulation. So that the money can't circulate inclusively among a society. When a total deposits increase without being followed by the allocation of a maximum and inclusive distribution of financing causes money to circulate in one place and can't touch another class of society, thus causing an increase in the poverty rate. Then, a total financing contribute negatively on it. So, it can't be fulfill the assumption of statistical description. Even though, a total financing also

International Journal of Islamic Economics and Finance (IJIEF), 4(SI), 87-120 | 103 
Ibrahim \& Indra | An Empirical Analysis of Islamic Banking (IBs) Contribution to Indonesia's Inclusive Growth.

evidenced contribute negatively on poverty and unemployment rate, but the contribution is unsignificant.

Whereas, in a short-term, IBs has evidence to has a relationship with inclusive growth. And the relationship or contribution are significance. In this case, the findings of a short-term estimation was in line with a research assumption and a previous research, Abd.Majid \& Kassim in term of GDP. While, in a poverty, unemployment, and gini ratio context, the result has rejected the statement of Susilo (2015), when it compared by the result in a short-term. But the rejection wasn't valid in a long-term analytical result. So, as a closing conclusion, IBs has contribute significantly on inclusive growth in a short-term, but it doesn't roundly applies in a long-term.

\subsection{Recommendation}

The findings of this analysis was only evidence the significance contribution of IBs on inclusive growth in a short-term. Based on it, a long-term contribution of IBs still cathegorized as the area that requires an extentions in order to accomplish it. And it is consider to refining this analytical literature. Specifically, consider to the findings on total financing, to upgrade the contribution of IBs on poverty and unemployment in a long-term, IBs is requires to develop a program that focus on society's economical improvement and refinement. It can be attained properly if IBs has its own Islamic social finance institutions. Where, IBs has an authority to manage its own ZISWAF funds. Therefore, an empowerment and improvement program by IBs will be more focused. Besides it, practically and theoritically, zakat, infak, and shodaqoh was focus on a poverty and economic equality. Moreover when it is applied in IBs which has a large total deposits and a complete of customer data. So, the practice of Islamic social funds management will be implemented maximally through of IBs. By its condition, it will be easier to achieve an inclusive growth in Indonesia. And it is an efficient recommendation to upgrade the contribution of IBs in achieve the goals of inclusive growth in Indonesia at this time. Therefore, The government needs to issue a policy to realize it. So that the banks has the authority to implement this program to support inclusive economic growth in Indonesia. 
Ibrahim \& Indra | An Empirical Analysis of Islamic Banking (IBs) Contribution to Indonesia's Inclusive Growth.

\section{References}

Adams, J., Khan, H. T., Raeside, R., \& White, D. (2007). Research method for graduate business and social science students. SAGE Publications India.

Akinbobola, T. O., \& Saibu, M. O. (2004). Income inequality, unemployment, and poverty in Nigeria: a vector autoregressive approach. The Journal of Policy Reform 7(3), 175-183.

Al Nasser, S. A., \& Muhammed, D. D. (2013). Introduction to history of Islamic banking in Malaysia . Humanomics, Vol.29 No.2, 80-87.

Alogoskoufis, G. (1991). On Error Correction Models: Specification, interpretation, estimation. Journal of Economic Surveys 5(1), 97-128.

Anand, R., Mishra, S., \& Peiris, S. J. (2013). Inclusive Growth: Measurement and determinants. IMF Working Paper Vol.13 No.135, 01-17.

Aris, N. A., Othman, R., Mohd Azli, R., Sahri, M., Abdul Razak, D., \& Abdul Rahman, Z. (2013). Islamic Banking products: Regulations, issues, and challenges. The Journal of Applied Business Research 29(4), 1145-1156.

Ascarya. (2010). Roles of Indonesia's Islamic banking in achieving macroeconomic objectives. International Summit Ikatan Ilmuwan Indonesia Internasional (I-4) "Pengelolaan Sumber Daya Ekonomi Menuju Indonesia Maju dan Mandiri Melalui perkembangan IImu Ekonomi Terbaru" (pp. 01-22). Jakarta: DIKTI.

Bahmani-Oskooee, M., \& Bohl, M. T. (2000). German monetary unification and the stability of the German M3 money demand function. Economic Letters 66, 203-208.

BPS. (2011). Perkembangan indeks produksi manufaktur besar dan sedang 2008-2011. Jakarta: Badan Pusat Statistik.

BPS. (2012). Perkembangan indeks produksi manufaktur 2010-2012. Jakarta: Badan Pusat Statistik.

BPS. (2013). Perkembangan indeks produksi industri manufaktur 2011-2013. Jakarta: Badan Pusat Statistik.

BPS. (2015). Perkembangan indeks produksi manufaktur 2013-2015. Jakarta: Badan Pusat Statistik.

BPS. (2016). Perkembangan indeks produksi industri manufaktur 2014-2016. Jakarta: Badan Pusat Statistik.

BPS. (2017). Perkembangan indeks produksi industri manufaktur 2015-2017. Jakarta: Badan Pusat Statistik. 
Ibrahim \& Indra | An Empirical Analysis of Islamic Banking (IBs) Contribution to Indonesia's Inclusive Growth.

BPS. (2019). Perkembangan indeks produksi manufaktur 2017-2019. Jakarta: Badan Pusat Statistik.

BPS. (2020, September 15). Poverty and inequality. Retrieved from Central Bureau of Statistics: https://www.bps.go.id/subject/23/kemiskinandan-ketimpangan.html

Catalano, M. T., Leise, T. L., \& Pfaff, T. J. (2009). Measuring resources inequality: The gini coefficient. Numeracy 2(2), 01-22.

Chen, C. (2002). Robust regression and outlier detection with the robustreg procedure. SUGI: Statistics and Data Analysis 265(27), 01-13.

Chowdhury, A., \& Zuk, P. (2018). From crisis to crisis: Capitalism, chaos and constant unpredictability. The Economic and Labour Relations Review , 01-19.

Eangle, R. F., \& Granger, C. J. (1987). Cointegration and error correction: Representation, estiimation, and testing. Econometrica 55, 251-276.

Eberstadt, N. (2008). The Poverty of the official. California: The Milken Institute Review.

Edeme, R. K. (2018). Revisiting the economic growth-welfare linkages: Empirical evidence from Nigeria. Asian Themes in Social Science Research, 1(1), 28-33.

El Ayyubi, S., Anggraeni, L., \& Mahiswari, A. D. (2017). The effect of Islamic banking to economic growth in Indonesia. Jurnal Al-Muzara'ah 5(2), 88-106.

Elliot, G., Rothenberg, T. J., \& Stock, J. H. (1996). Efficient tests for an autoregressive unit root. Econometrica 64(4), 813-836.

Farris, F. A. (2010). The gini index and measures of inequality. The American Mathematical Monthly 117(10), 851-864.

Goedhart, T., Halberstadt, V., Kapteyn, A., \& Praag, B. v. (1977). The poverty line: Concept and measurement. The Journal of Human Resources is currently published by University of Wisconsin Press 12(4), 503-520.

Gujarati, D. (2003). Ekonometrika dasar. Jakarta: Penerbit Erlangga.

Haller, A. P. (2012). Concepts of economic growth and development. challenges of crisis and of knowledge. Economy Transdisciplinarity Cognition, 15(1), 66-71.

Hamzah, R. A., \& Handri. (2017). Analisis interest rate pass-through pada mekanisme transmisi kebijakan moneter Indonesia. Jurnal of Economics and Business, 1(1), 125-135. 
Ibrahim \& Indra | An Empirical Analysis of Islamic Banking (IBs) Contribution to Indonesia's Inclusive Growth.

Hart, C. (1998). Doing a literature review: Releasing the social science research imagination. London/Thousand Oaks/New Delhi: SAGE Publications.

Hassler, U., \& Wolters, J. (2005). Autoregressive distributed lag models and cointegration. Diskussionsbeiträge, No.2005/22, 01-14.

Hatanaka, T. (1995). Time series based econometrics: unit roots and cointegration. Oxford: Oxford University Press.

Ibrahim, M. Y., Ismail, N., \& Sumandar, A. (2019). A comparative study of Khaldun, Smith, and Marx thinking about the labor theory of value. International Journal of Advanced Research in Islamic and Humanities, 1(3), 01-08.

ILO. (2015). International Labor Organization. Retrieved from Unemployment Rate: http://www.ilo.org/ilostatfiles/Documents/LFEP\%20Methodology\%202015.pdf

Ismail, A. G., \& Shaikh, S. A. (2017). Role of Islamic economics and finance in sustainable development goals. IESTAC Working Paper 5, 02-16.

Ismal, R. (2010). Volatility of the returns and expected losses of Islamic bank financing. International Journal of Islamic and Middle Eastern Finance and Management, 3(3), 267-279.

Ivkovic, A. F. (2016). Limitations of the GDP as a measure of progress and well-being. Ekonomski Vjesnik/Econviews God.XXIX BR.1, 257-272.

Jia, Y. B. (2017). Polynomial interpolation. Com S 477(577), 01-10.

Johansen, S. (1992). Cointegration in Partial systems and the efficiency of single-equation analysis. Journal of Econometrics 52(3), 389-402.

Kasmir. (2005). Pemasaran jasa. Jakarta: Graya Grafindo Persada.

Kusumawati, P. L., Elhorst, J. P., \& Haan, J. D. (2016). The inclusive growth concept: strenghts, weakness, and a research agenda for Indonesia. In R. L. Holzhacker, R. Wittek, \& J. Woltjer, Decentralization and Governance in Indonesia (pp. 145-168). Switzerland: Springer International Publishing.

Mowafi, M., \& Khawaja, M. (2005). Poverty. Journal Epidemiol Community Health 59, 260-264.

OJK. (2020). Sharia banking statistics. Jakarta: Otoritas Jasa Keuangan.

Onyema, J. I., \& Odeiem-Ogulu, S. (2019). Deposit composition of deposit money banks and return on equity in Nigeria. Economics and Social Sciences Academic Journal 1(2), 01-11.

Pagan, A. (1985). Time Series behavour and dynamic specification. Oxford Bulletin of Economics and Statistics 47, 199-211. 
Ibrahim \& Indra | An Empirical Analysis of Islamic Banking (IBs) Contribution to Indonesia's Inclusive Growth.

Pesaran, M. H., \& Shin, Y. (1995). An autoregressive distributed lag modelling approach to cointegration analysis. Symposium at the Centennial of Ragnar Frisch (pp. 01-24). Oslo: The Norwegian Academy of Science and Letters.

Phillips, A. W. (1957). Stabilization policy and the time form of lagged responses. Economic Journal 67, 265-277.

Pietak, L. (2014). Review of theories and models of economic growth. comparative economic research, Vol.17 No.1, 45-60.

Rivai, V., \& Arifin, A. (2010). Islamic banking: sebuah teori, konsep, dan aplikasi. Jakarta: Bumi Aksara.

Rousseeuw, R. J., \& Leroy, A. M. (1987). Robust regression and outlier detection. New York: John Wiley and Sons.

Said, S. E., \& Dickey, D. (1984). Testing for unit roots in autoregressive moving average modes with unknow order. Biometrika 71, 599-607.

Stewart, F. (2000). Income distribution and development. QEH Working Paper Series 37, 01-36.

Suryanarayana, M. H. (2013). Inclusive growth: A sustainable perspective. Goregaon East, Mumbai : Indira Gandhi Institute of Development Research .

Tulak, D. Y., Junaidi, \& Utami, I. T. (2017). An application of autoregressive distributed lag (ARDL) to the consumer price index (CPI) Modeling of groceries and finished food group that affecting inflation in Palu city. Natural Science-Journal of Science and Technology 6(3), 313-320.

Varquez, F., Tabak, B. M., \& Souto, M. (2012). A macro stress test model of credit risk for the Brazilian Banking Sector. . Journal of Financial Stability Vol.8 No.2, 69-83.

Wesselink, B., Bakkes, J., Best, A., Hinterberger, F., \& Brink, P. T. (2007). Measurement beyond GDP. Beyond GDP: measuring progress, true wealth, and the well being of nations international conference (pp. 01-17). Brussels: Europian Commision.

Zaretta, B., \& Yovita, L. (2019). Harga saham, nilai tukar mata uang, dan tingkat suku bunga acuan dalam model autoregressive distributed lag. Jurnal Penelitian Ekonomi dan Bisnis Vol.4 No.1, 09-22. 
Ibrahim \& Indra | An Empirical Analysis of Islamic Banking (IBs) Contribution to Indonesia's Inclusive Growth.

\section{Appendix}

Attachment 1 Unit Root Test

\begin{tabular}{|c|c|c|c|c|c|c|}
\hline Level & LNTD & LNTF & LNGDP & LNPR & LNUR & LNGR \\
\hline ADF Test Statistic & -3.914 & -5.265 & -11.208 & -1.687 & -1.347 & -0.851 \\
\hline 1st difference & LNTD & LNTF & LNGDP & LNPR & LNUR & LNGR \\
\hline ADF Test Statistic & -4.472 & -15.478 & -7.314 & -2.382 & -7.286 & -1.776 \\
\hline 2nd difference & LNTD & LNTF & LNGDP & LNPR & LNUR & LNGR \\
\hline ADF Test Statistic & -7.936 & -8.617 & -7.098 & -10.489 & -7.718 & -9.854 \\
\hline \multirow{3}{*}{ Test Critical Value } & 1\% level & & -3.486551 & \\
\cline { 2 - 7 } & $5 \%$ level & \multicolumn{7}{|c|}{-2.886074} \\
\cline { 2 - 7 } & 10\% level & \multicolumn{7}{|c|}{} \\
\hline
\end{tabular}

\begin{tabular}{|c|c|c|c|c|c|c|}
\hline \multicolumn{7}{|c|}{ Level } \\
\hline \multicolumn{4}{|c|}{$\begin{array}{l}\text { Null Hypothesis: LNTD has a unit root } \\
\text { Exogenous: Constant } \\
\text { Lag Length: } 1 \text { (Automatic - based on SIC, } \\
\text { maxlag=12) }\end{array}$} & \multicolumn{3}{|c|}{$\begin{array}{l}\text { Null Hypothesis: LNTF has a unit root } \\
\text { Exogenous: Constant } \\
\text { Lag Length: } 2 \text { (Automatic - based on SIC, } \\
\text { maxlag=12) }\end{array}$} \\
\hline & & t-Statistic & Prob.* & & t-Statistic & Prob.* \\
\hline \multicolumn{4}{|c|}{$\begin{array}{l}\text { Augmented Dickey- } \\
\text { Fuller test statistic }\end{array}$} & \multicolumn{3}{|l|}{ Augmented Dickey- } \\
\hline $\begin{array}{l}\text { Test critical } \\
\text { values: }\end{array}$ & \begin{tabular}{|c|}
$1 \%$ \\
level \\
$5 \%$ \\
level \\
$10 \%$ \\
level
\end{tabular} & $\begin{array}{l}-3.486551 \\
-2.886074 \\
-2.579931\end{array}$ & & $\begin{array}{lc}\text { Test critical } & 1 \% \\
\text { values: } & \text { level } \\
& 5 \% \\
& \text { level } \\
& 10 \% \\
& \text { level }\end{array}$ & $\begin{array}{l}-3.487046 \\
-2.886290\end{array}$ & \\
\hline \multicolumn{4}{|c|}{ *MacKinnon (1996) one-sided p-values. } & \multicolumn{3}{|c|}{ *MacKinnon (1996) one-sided p-values. } \\
\hline \multicolumn{4}{|c|}{$\begin{array}{l}\text { Null Hypothesis: LNGDP has a unit root } \\
\text { Exogenous: Constant } \\
\text { Lag Length: } 2 \text { (Automatic - based on SIC, } \\
\text { maxlag=12) }\end{array}$} & \multicolumn{3}{|c|}{$\begin{array}{l}\text { Null Hypothesis: LNPR has a unit root } \\
\text { Exogenous: Constant } \\
\text { Lag Length: } 7 \text { (Automatic - based on SIC, } \\
\text { maxlag=12) }\end{array}$} \\
\hline & & & & & t-Statistic & Prob.* \\
\hline \multicolumn{2}{|c|}{$\begin{array}{l}\text { Augmented Dickey- } \\
\text { Fuller test statistic }\end{array}$} & -11.20885 & 0.0000 & $\begin{array}{l}\text { Augmented Dickey- } \\
\text { Fuller test statistic }\end{array}$ & -1.687943 & 0.4346 \\
\hline $\begin{array}{l}\text { Test critical } \\
\text { values: }\end{array}$ & $\begin{array}{c}1 \% \\
\text { level } \\
5 \% \\
\text { level } \\
10 \% \\
\text { level }\end{array}$ & $\begin{array}{l}\text { Test critical } \\
\text { values: }\end{array}$ & $\begin{array}{l}1 \% \text { level } \\
5 \% \text { level }\end{array}$ & $\begin{array}{lc}\text { Test critical } & 1 \% \\
\text { values: } & \text { level } \\
& 5 \% \\
& \text { level } \\
& 10 \% \\
& \text { level }\end{array}$ & -3.489659 & \\
\hline \multicolumn{4}{|c|}{ *MacKinnon (1996) one-sided p-values. } & \multicolumn{3}{|c|}{ *MacKinnon (1996) one-sided p-values. } \\
\hline \multicolumn{4}{|c|}{$\begin{array}{l}\text { Null Hypothesis: LNUR has a unit root } \\
\text { Exogenous: Constant } \\
\text { Lag Length: } 6 \text { (Automatic - based on SIC, } \\
\text { maxlag=12) }\end{array}$} & \multicolumn{3}{|c|}{$\begin{array}{l}\text { Null Hypothesis: LNGR has a unit root } \\
\text { Exogenous: Constant } \\
\text { Lag Length: } 7 \text { (Automatic - based on SIC, } \\
\text { maxlag=12) }\end{array}$} \\
\hline & & $\mathrm{t}$-Statistic & Prob.* & & t-Statistic & Prob.* \\
\hline
\end{tabular}

International Journal of Islamic Economics and Finance (IJIEF), 4(SI), 87-120 109 
Ibrahim \& Indra | An Empirical Analysis of Islamic Banking (IBs) Contribution to Indonesia's Inclusive Growth.

\begin{tabular}{|c|c|c|c|c|c|c|c|}
\hline \multicolumn{2}{|c|}{$\begin{array}{l}\text { Augmented Dickey- } \\
\text { Fuller test statistic }\end{array}$} & \multirow{2}{*}{-1.347866} & 0.6052 & \multicolumn{2}{|c|}{$\begin{array}{l}\text { Augmented Dickey- } \\
\text { Fuller test statistic }\end{array}$} & $\begin{array}{r}-0.851480 \\
-3.489659\end{array}$ & 0.8000 \\
\hline $\begin{array}{l}\text { Test critical } \\
\text { values: }\end{array}$ & $\begin{array}{c}1 \% \\
\text { level } \\
5 \% \\
\text { level } \\
10 \% \\
\text { level }\end{array}$ & & & $\begin{array}{l}\text { Test critical } \\
\text { values: }\end{array}$ & $\begin{array}{c}1 \% \\
\text { level } \\
5 \% \\
\text { level } \\
10 \% \\
\text { level }\end{array}$ & -3.489659 & \\
\hline \multicolumn{4}{|c|}{${ }^{*}$ MacKinnon (1996) one-sided p-values. } & \multicolumn{4}{|c|}{${ }^{*}$ MacKinnon (1996) one-sided p-values. } \\
\hline \multicolumn{8}{|c|}{ 1st Difference } \\
\hline \multicolumn{4}{|c|}{$\begin{array}{l}\text { Null Hypothesis: D(LNTD) has a unit root } \\
\text { Exogenous: Constant } \\
\text { Lag Length: } 2 \text { (Automatic - based on SIC, } \\
\text { maxlag=12) }\end{array}$} & \multicolumn{4}{|c|}{$\begin{array}{l}\text { Null Hypothesis: } \mathrm{D}(\mathrm{LNTF}) \text { has a unit root } \\
\text { Exogenous: Constant } \\
\text { Lag Length: } 0 \text { (Automatic - based on SIC, } \\
\text { maxlag=12) }\end{array}$} \\
\hline & & t-Statistic & Prob.* $^{*}$ & & & t-Statistic & Prob. $^{*}$ \\
\hline \multicolumn{2}{|c|}{$\begin{array}{l}\text { Augmented Dickey- } \\
\text { Fuller test statistic }\end{array}$} & -4.472811 & 0.0004 & \multicolumn{2}{|c|}{$\begin{array}{l}\text { Augmented Dickey- } \\
\text { Fuller test statistic }\end{array}$} & -15.47899 & 0.0000 \\
\hline $\begin{array}{l}\text { Test critical } \\
\text { values: }\end{array}$ & $\begin{array}{c}\% \\
\text { level } \\
5 \% \\
\text { level } \\
10 \% \\
\text { level }\end{array}$ & -3.487550 & & $\begin{array}{l}\text { Test critical } \\
\text { values: }\end{array}$ & $\begin{array}{c}1 \% \\
\text { level } \\
5 \% \\
\text { level } \\
10 \% \\
\text { level }\end{array}$ & $\begin{array}{l}-2.886074 \\
-2.579931\end{array}$ & \\
\hline \multicolumn{4}{|c|}{ *MacKinnon (1996) one-sided p-values. } & \multicolumn{4}{|c|}{ *MacKinnon (1996) one-sided p-values. } \\
\hline \multicolumn{4}{|c|}{$\begin{array}{l}\text { Null Hypothesis: D(LNGDP) has a } \\
\text { unit root } \\
\text { Exogenous: Constant } \\
\text { Lag Length: } 10 \text { (Automatic - based on SIC, } \\
\text { maxlag=12) }\end{array}$} & \multicolumn{4}{|c|}{$\begin{array}{l}\text { Null Hypothesis: D(LNPR) has a } \\
\text { unit root } \\
\text { Exogenous: Constant } \\
\text { Lag Length: } 6 \text { (Automatic - based on SIC, } \\
\text { maxlag=12) }\end{array}$} \\
\hline & & & & & & t-Statistic & Prob. $^{*}$ \\
\hline \multicolumn{2}{|c|}{$\begin{array}{l}\text { Augmented Di } \\
\text { Fuller test statistic }\end{array}$} & -7.314160 & 0.0000 & \multicolumn{2}{|c|}{$\begin{array}{l}\text { Augmented Dickey- } \\
\text { Fuller test statistic }\end{array}$} & -2.382851 & 0.1489 \\
\hline $\begin{array}{l}\text { Test critica } \\
\text { values: }\end{array}$ & $\begin{array}{c}1 \% \\
\text { level } \\
5 \% \\
\text { level } \\
10 \% \\
\text { level }\end{array}$ & $\begin{array}{l}\text { Test critica } \\
\text { values: }\end{array}$ & $\begin{array}{l}1 \% \text { level } \\
5 \% \text { level } \\
10 \% \text { level }\end{array}$ & $\begin{array}{l}\text { Test critical } \\
\text { values: }\end{array}$ & $\begin{array}{c}1 \% \\
\text { level } \\
5 \% \\
\text { level } \\
10 \% \\
\text { level }\end{array}$ & $\begin{array}{l}-3.489659 \\
-2.887425\end{array}$ & \\
\hline \multicolumn{4}{|c|}{ *MacKinnon (1996) one-sided p-values. } & \multicolumn{4}{|c|}{ *MacKinnon (1996) one-sided p-values. } \\
\hline \multicolumn{4}{|c|}{$\begin{array}{l}\text { Null Hypothesis: D(LNUR) has a unit root } \\
\text { Exogenous: Constant } \\
\text { Lag Length: } 5 \text { (Automatic - based on SIC, } \\
\text { maxlag=12) }\end{array}$} & \multicolumn{4}{|c|}{$\begin{array}{l}\text { Null Hypothesis: D(LNGR) has a unit root } \\
\text { Exogenous: Constant } \\
\text { Lag Length: } 12 \text { (Automatic - based on SIC, } \\
\text { maxlag=12) }\end{array}$} \\
\hline & & t-Statistic & Prob.* & & & t-Statistic & Prob. $^{*}$ \\
\hline \multicolumn{2}{|c|}{$\begin{array}{l}\text { Augmented Dickey- } \\
\text { Fuller test statistic }\end{array}$} & -7.286072 & 0.0000 & \multicolumn{2}{|c|}{$\begin{array}{l}\text { Augmented Dickey- } \\
\text { Fuller test statistic }\end{array}$} & -1.776506 & 0.3903 \\
\hline $\begin{array}{l}\text { Test critical } \\
\text { values: }\end{array}$ & $\begin{array}{c}1 \% \\
\text { level } \\
5 \% \\
\text { level }\end{array}$ & -3.489117 & & $\begin{array}{l}\text { Test critical } \\
\text { values: }\end{array}$ & $\begin{array}{c}1 \% \\
\text { level } \\
5 \% \\
\text { level } \\
\end{array}$ & -3.493129 & \\
\hline
\end{tabular}


Ibrahim \& Indra | An Empirical Analysis of Islamic Banking (IBs) Contribution to Indonesia's Inclusive Growth.

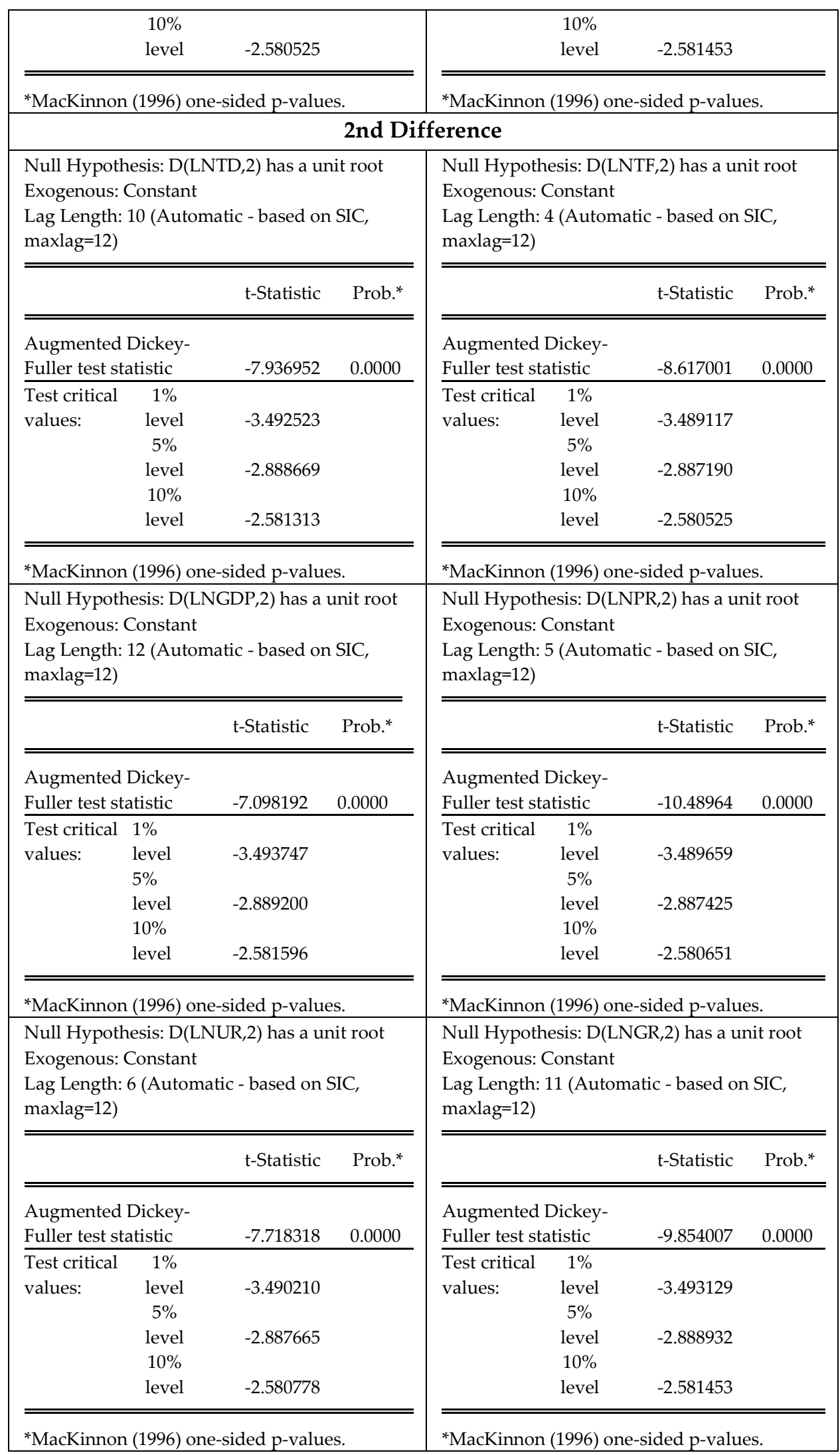


Ibrahim \& Indra | An Empirical Analysis of Islamic Banking (IBs) Contribution to Indonesia's Inclusive Growth.

Attachment 2 Lag Determination

\begin{tabular}{|c|c|c|c|c|c|c|c|}
\hline \multirow{2}{*}{ Signif. } & $I(0)$ & $I(1)$ & \multirow{2}{*}{$\begin{array}{l}\text { Lag } \\
\text { Length }\end{array}$} & \multicolumn{4}{|c|}{ Computed F-Statistics } \\
\hline & \multicolumn{2}{|c|}{ Asymptotic: $n=1000$} & & LNGDP & LNPR & LNUR & LNGR \\
\hline $10 \%$ & 2.63 & 3.35 & $1(1,1,1)$ & 14.98285 & 3.726793 & 2.093083 & 6.924682 \\
\hline $5 \%$ & 3.1 & 3.87 & $2(2.2,2)$ & 7.478574 & 2.140897 & 3.416080 & 4.449665 \\
\hline $2,50 \%$ & 3.55 & 4.38 & $3(3,3,3)$ & 4.904855 & 1.918977 & 4.757787 & 3.364842 \\
\hline $1 \%$ & 4.13 & 5 & $4(4,4,4)$ & 5.377741 & 1.932132 & 5.827458 & 3.203494 \\
\hline
\end{tabular}

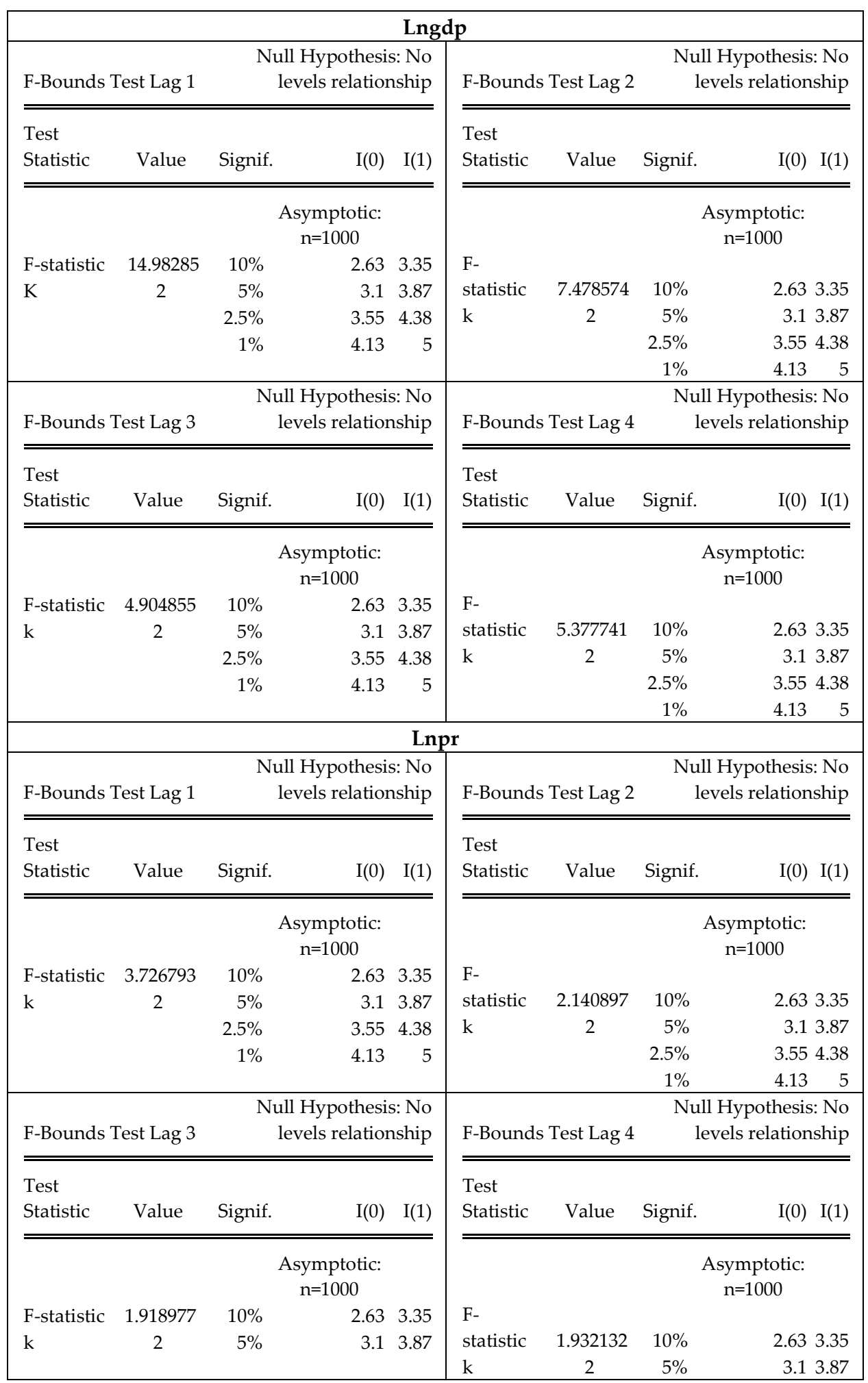


Ibrahim \& Indra | An Empirical Analysis of Islamic Banking (IBs) Contribution to Indonesia's Inclusive Growth.

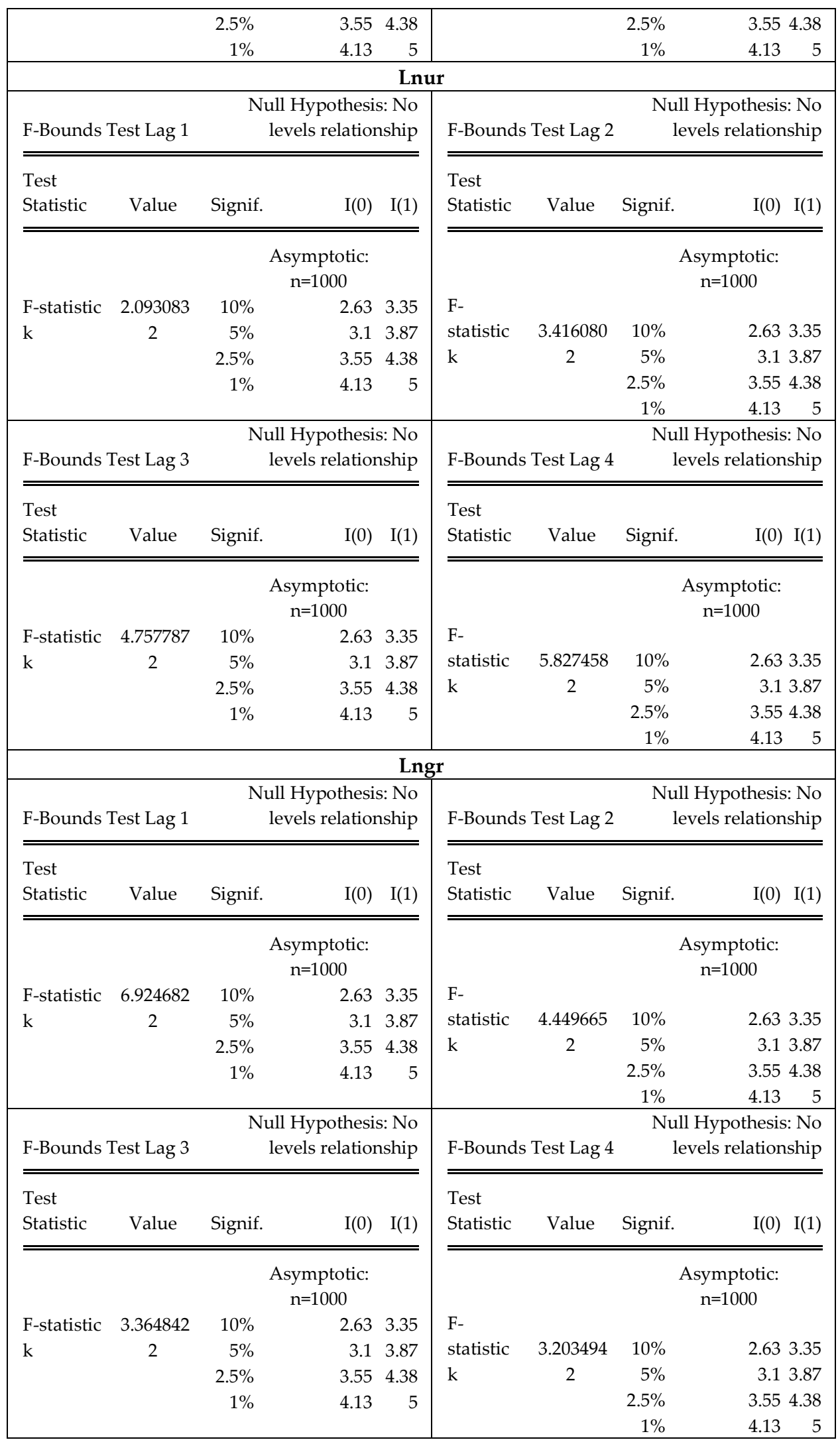


Ibrahim \& Indra | An Empirical Analysis of Islamic Banking (IBs) Contribution to Indonesia's Inclusive Growth.

Attachment 3 BLGM Test Result

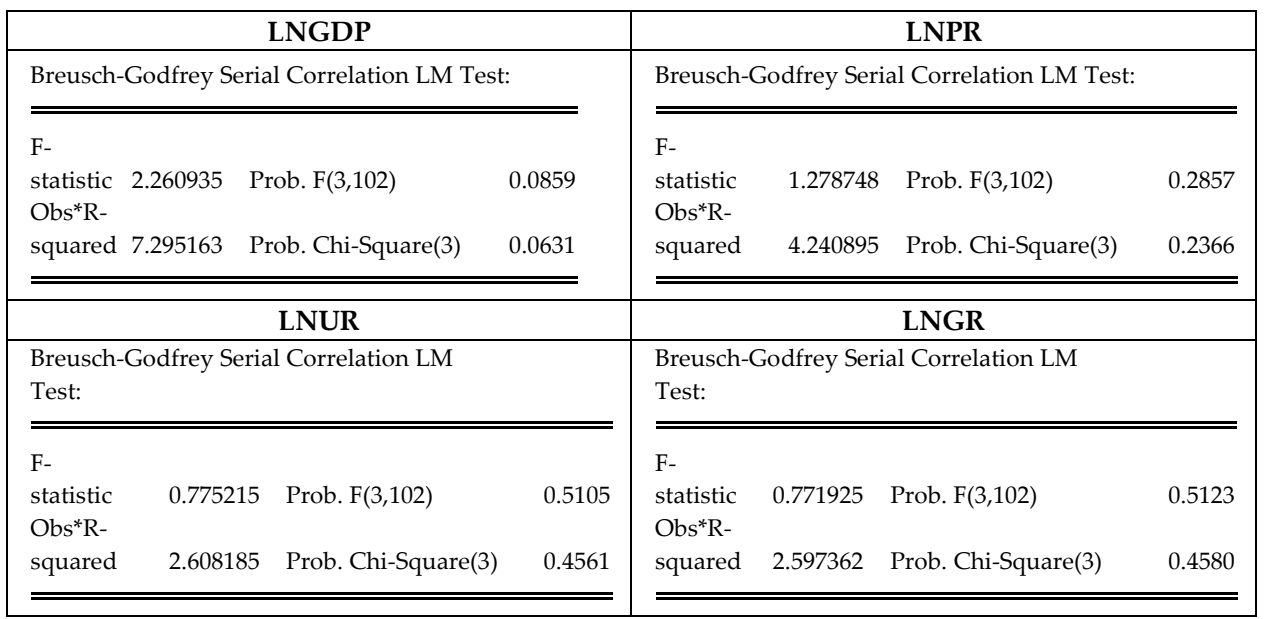


Ibrahim \& Indra | An Empirical Analysis of Islamic Banking (IBs) Contribution to Indonesia's Inclusive Growth.

Attachment 4 Long Run Form and Bound Test

\begin{tabular}{|l|r|r|r|r|r|r|r|r|}
\hline & \multicolumn{2}{|c|}{ LNGDP } & \multicolumn{2}{c|}{ LNPR } & \multicolumn{2}{c|}{ LNUR } & \multicolumn{2}{c|}{ LNGR } \\
\cline { 2 - 9 } & Coefficient & Prob & Coefficient & Prob & Coefficient & Prob & Coefficient & Prob \\
\hline LNTD & 1.754424 & 0.4202 & -26.76932 & 0.8646 & -0.086862 & 0.4785 & -0.307593 & 0.0014 \\
\hline LNTF & -1.563738 & 0.4460 & 28.27025 & 0.8646 & -0.128297 & 0.3243 & 0.298745 & 0.0036 \\
\hline C & -0.474859 & 0.7705 & -7.622406 & 0.8646 & 0.097103 & 0.0000 & -0.861864 & 0.0000 \\
\hline
\end{tabular}

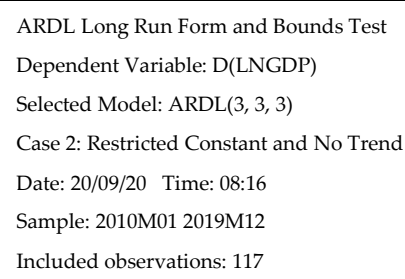

\begin{tabular}{|c|c|c|c|}
\hline \multicolumn{4}{|c|}{ Conditional Error Correction Regression } \\
\hline Variable & Coefficient & Std. Error t-Statistic & Prob. \\
\hline C & 0.409306 & $0.098830 \quad 4.141503$ & 0.0001 \\
\hline LNGDP $(-1)^{*}$ & -0.069720 & $0.017404-4.006034$ & 0.0001 \\
\hline $\operatorname{LNTD}(-1)$ & 0.084269 & $0.022815 \quad 3.693486$ & 0.0004 \\
\hline LNTF(-1) & -0.057284 & $0.017260-3.318855$ & 0.0012 \\
\hline $\begin{array}{l}\text { D(LNGDP(- } \\
1) \text { ) }\end{array}$ & 0.736592 & $\begin{array}{lll}0.092560 & 7.957952\end{array}$ & 0.0000 \\
\hline $\begin{array}{c}\text { D(LNGDP(- } \\
2))\end{array}$ & -0.045390 & $0.097630-0.464923$ & 0.6429 \\
\hline D(LNTD) & 0.023630 & $0.028943 \quad 0.816427$ & 0.4161 \\
\hline $\mathrm{D}(\operatorname{LNTD}(-1))$ & -0.076626 & $0.030286-2.530073$ & 0.0129 \\
\hline $\mathrm{D}(\operatorname{LNTD}(-2))$ & -0.000940 & $0.027984-0.033573$ & 0.9733 \\
\hline D(LNTF) & -0.020204 & $0.019709-1.025116$ & 0.3077 \\
\hline $\mathrm{D}(\operatorname{LNTF}(-1))$ & 0.028275 & $0.023511 \quad 1.202619$ & 0.2318 \\
\hline $\mathrm{D}(\operatorname{LNTF}(-2))$ & 0.009717 & $0.020096 \quad 0.483535$ & 0.6297 \\
\hline \multicolumn{4}{|c|}{ * p-value incompatible with $\mathrm{t}$-Bounds distribution. } \\
\hline \multirow{2}{*}{\multicolumn{4}{|c|}{$\begin{array}{l}\text { Levels Equation } \\
\text { Case 2: Restricted Constant and No Trend }\end{array}$}} \\
\hline & & & \\
\hline Variable & Coefficient & Std. Error t-Statistic & Prob. \\
\hline LNTD & 1.754424 & $0.160304 \quad 7.539909$ & 0.0000 \\
\hline LNTF & -1.563738 & $0.171570-4.788861$ & 0.0000 \\
\hline C & -0.474859 & $0.149479 \quad 39.27437$ & 0.0000 \\
\hline \multicolumn{4}{|c|}{$\mathrm{EC}=\mathrm{LNGDP}-\left(1.2087^{*}\right.$ LNTD $\left.-0.8216^{*} \mathrm{LNTF}+5.8707\right)$} \\
\hline \multicolumn{4}{|c|}{ ARDL Long Run Form and Bounds Test } \\
\hline \multicolumn{4}{|c|}{ Dependent Variable: D(LNUR) } \\
\hline \multicolumn{4}{|c|}{ Selected Model: $\operatorname{ARDL}(3,3,3)$} \\
\hline \multicolumn{4}{|c|}{ Case 2: Restricted Constant and No Trend } \\
\hline \multicolumn{4}{|c|}{ Date: 20/09/20 Time: 08:23 } \\
\hline \multicolumn{4}{|c|}{ Sample: 2010M01 2019M12 } \\
\hline \multicolumn{4}{|c|}{ Included observations: 117} \\
\hline \multicolumn{4}{|c|}{ Conditional Error Correction Regression } \\
\hline Variable & Coefficien & nt Std. Error t-Stati & Prob. \\
\hline
\end{tabular}

ARDL Long Run Form and Bounds Test

Dependent Variable: D(LNPR)

Selected Model: $\operatorname{ARDL}(1,1,1)$

Case 2: Restricted Constant and No Trend

Date: 20/09/20 Time: 08:17

Sample: 2010M01 2019M12

Included observations: 119

\begin{tabular}{|c|c|c|c|c|}
\hline \multicolumn{5}{|c|}{ Conditional Error Correction Regression } \\
\hline Variable & Coefficient & Std. Error & t-Statistic & Prob. \\
\hline C & -0.020042 & 0.013009 & -1.540623 & 0.1262 \\
\hline $\operatorname{LNPR}(-1)^{*}$ & -0.002629 & 0.015395 & -0.170792 & 0.8647 \\
\hline $\operatorname{LNTD}(-1)$ & -0.070386 & 0.020869 & -3.372719 & 0.0010 \\
\hline $\operatorname{LNTF}(-1)$ & 0.074333 & 0.021983 & 3.381450 & 0.0010 \\
\hline $\mathrm{D}$ (LNTD) & -0.086600 & 0.051930 & -1.667607 & 0.0982 \\
\hline D(LNTF) & 0.036124 & 0.035209 & 1.025993 & 0.3071 \\
\hline
\end{tabular}

* p-value incompatible with t-Bounds distribution.

\begin{tabular}{ccccc}
\hline \hline \multicolumn{5}{c}{ Levels Equation } \\
\multicolumn{5}{c}{ Case 2: Restricted Constant and No Trend } \\
\hline \hline Variable & Coefficient & Std. Error & t-Statistic & Prob. \\
\hline \hline \multirow{2}{*}{ LNTD } & -26.76932 & 156.5999 & -0.170941 & 0.8646 \\
LNTF & 28.27025 & 166.4368 & 0.169856 & 0.8654 \\
C & -7.622406 & 45.90586 & -0.166044 & 0.8684 \\
\hline \hline
\end{tabular}

EC $=$ LNPR $-\left(-26.7693^{*}\right.$ LNTD $+28.2703^{*}$ LNTF -7.6224$)$

ARDL Long Run Form and Bounds Test

Dependent Variable: D(LNGR)

Selected Model: ARDL $(3,3,3)$

Case 2: Restricted Constant and No Trend

Date: 20/09/20 Time: 08:24

Sample: 2010M01 2019M12

Included observations: 117

\begin{tabular}{lll}
\hline \hline Conditional Error Correction Regression & \\
\hline \hline Variable $\quad$ Coefficient Std. Error & t-Statistic & Prob. \\
\hline \hline
\end{tabular}


Ibrahim \& Indra | An Empirical Analysis of Islamic Banking (IBs) Contribution to Indonesia's Inclusive Growth.

\begin{tabular}{|c|c|c|c|c|c|c|c|c|c|}
\hline C & 0.362018 & 0.083136 & 4.354517 & 0.0000 & C & -0.038409 & 0.012185 & -3.152205 & 0.0021 \\
\hline LNUR(-1)* & -0.124950 & 0.029115 & -4.291616 & 0.0000 & $\operatorname{LNGR}(-1)^{*}$ & -0.044565 & 0.013661 & -3.262220 & 0.0015 \\
\hline LNTD(-1) & -0.010853 & 0.015544 & -0.698243 & 0.4866 & LNTD(-1) & -0.013708 & 0.005962 & -2.299040 & 0.0235 \\
\hline LNTF(-1) & -0.016031 & 0.016423 & -0.976089 & 0.3313 & LNTF(-1) & 0.013314 & 0.006094 & 2.184815 & 0.0311 \\
\hline $\mathrm{D}(\operatorname{LNUR}(-1))$ & 0.480326 & 0.089525 & 5.365278 & 0.0000 & $\mathrm{D}(\operatorname{LNGR}(-1))$ & 0.788854 & 0.093956 & 8.395960 & 0.0000 \\
\hline $\mathrm{D}(\mathrm{LNUR}(-2))$ & 0.212724 & 0.092261 & 2.305669 & 0.0231 & $\mathrm{D}(\operatorname{LNGR}(-2))$ & -0.042026 & 0.094758 & -0.443508 & 0.6583 \\
\hline D(LNTD) & -0.046361 & 0.037167 & -1.247363 & 0.2150 & D(LNTD) & 0.007311 & 0.010456 & 0.699199 & 0.4860 \\
\hline $\mathrm{D}(\operatorname{LNTD}(-1))$ & -0.063958 & 0.038145 & -1.676723 & 0.0966 & $\mathrm{D}(\operatorname{LNTD}(-1))$ & 0.018934 & 0.010422 & 1.816758 & 0.0721 \\
\hline $\mathrm{D}(\operatorname{LNTD}(-2))$ & 0.043412 & 0.036260 & 1.197258 & 0.2339 & $\mathrm{D}(\operatorname{LNTD}(-2))$ & -0.001731 & 0.009779 & -0.177053 & 0.8598 \\
\hline $\mathrm{D}(\mathrm{LNTF})$ & -0.024393 & 0.027084 & -0.900641 & 0.3698 & $\mathrm{D}$ (LNTF) & 0.005313 & 0.007379 & 0.719959 & 0.4731 \\
\hline $\mathrm{D}(\operatorname{LNTF}(-1))$ & -0.024828 & 0.030177 & -0.822750 & 0.4125 & $\mathrm{D}(\operatorname{LNTF}(-1))$ & -0.008211 & 0.008773 & -0.935966 & 0.3514 \\
\hline $\mathrm{D}(\operatorname{LNTF}(-2))$ & -0.019230 & 0.026589 & -0.723234 & 0.4711 & $\mathrm{D}(\operatorname{LNTF}(-2))$ & -0.002998 & 0.007485 & -0.400585 & 0.6895 \\
\hline \multicolumn{5}{|c|}{${ }^{*} \mathrm{p}$-value incompatible with $\mathrm{t}$-Bounds distribution. } & \multicolumn{5}{|c|}{${ }^{*}$ p-value incompatible with t-Bounds distribution. } \\
\hline \multicolumn{5}{|c|}{ Levels Equation } & \multicolumn{5}{|c|}{ Levels Equation } \\
\hline \multicolumn{5}{|c|}{ Case 2: Restricted Constant and No Trend } & \multicolumn{5}{|c|}{ Case 2: Restricted Constant and No Trend } \\
\hline Variable & Coefficient & Std. Error & t-Statistic & Prob. & Variable & Coefficient & Std. Error & $\mathrm{t}$-Statistic & Prob. \\
\hline LNTD & -0.086862 & 0.122118 & -0.711292 & 0.4785 & LNTD & -0.307593 & 0.093907 & -3.275501 & 0.0014 \\
\hline LNTF & -0.128297 & 0.129540 & -0.990410 & 0.3243 & LNTF & 0.298745 & 0.100210 & 2.981195 & 0.0036 \\
\hline $\mathrm{C}$ & 2.897311 & 0.097103 & 29.83744 & 0.0000 & $\mathrm{C}$ & -0.861864 & 0.077792 & -11.07903 & 0.0000 \\
\hline \multicolumn{5}{|c|}{$\mathrm{EC}=\mathrm{LNUR}-\left(-0.0869^{*}\right.$ LNTD $\left.-0.1283^{*} \mathrm{LNTF}+2.8973\right)$} & \multicolumn{5}{|c|}{$\mathrm{EC}=\mathrm{LNGR}-\left(-0.3076^{*} \mathrm{LNTD}+0.2987^{*}\right.$ LNTF -0.8619$)$} \\
\hline
\end{tabular}

International Journal of Islamic Economics and Finance (IJIEF), 4(SI), 87-120 116 
Ibrahim \& Indra | An Empirical Analysis of Islamic Banking (IBs) Contribution to Indonesia's Inclusive Growth.

Attachment 5 Error Correction Model Estimation

\begin{tabular}{|l|r|r|r|r|}
\hline & LNGDP (3,3,3) & \multicolumn{1}{|c|}{ LNPR (1,1,1) } & \multicolumn{1}{c|}{ LNUR $(\mathbf{3 , 3}, \mathbf{3})$} & \multicolumn{1}{c|}{ LNGR (3,3,3) } \\
\hline CointEq(-1) & -2.665390 & -0.002629 & -0.124950 & -0.044565 \\
\hline Prob & 0.0000 & 0.0002 & 0.0000 & 0.0003 \\
\hline
\end{tabular}

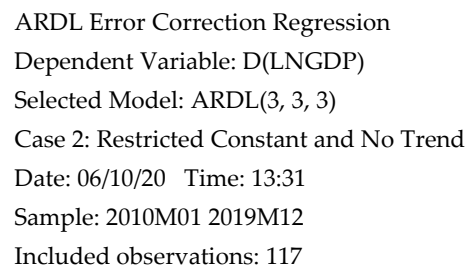

\begin{tabular}{lllll}
\hline \hline Variable & Coefficient & Std. Error & t-Statistic & Prob. \\
\hline \hline D(LNGDP(-1)) & 0.915627 & 0.181370 & 5.048390 & 0.0000 \\
D(LNGDP(-2)) & 0.326556 & 0.101230 & 3.225876 & 0.0017 \\
D(LNTF) & 7.161266 & 9.356966 & 0.765341 & 0.4458 \\
D(LNTF(-1)) & 10.64442 & 9.490810 & 1.121550 & 0.2646 \\
$D($ LNTF(-2)) & 5.951904 & 8.733188 & 0.681527 & 0.4970 \\
D(LNTD) & -3.650392 & 12.25156 & -0.297953 & 0.7663 \\
D(LNTD(-1)) & 13.15083 & 11.90523 & 1.104626 & 0.2718 \\
D(LNTD(-2)) & -17.75667 & 11.18937 & -1.586923 & 0.1155 \\
CointEq(-1)* & -2.665390 & 0.241557 & -11.03419 & 0.0000 \\
\hline \hline R-squared & 0.801357 & Mean dependent var & 0.006239 \\
Adjusted R-squared & 0.786643 & S.D. dependent var & 6.680508 \\
S.E. of regression & 3.085766 & Akaike info criterion & 5.165280 \\
Sum squared resid & 1028.371 & Schwarz criterion & 5.377755 \\
Log likelihood & -293.1689 & Hannan-Quinn criter. & 5.251542 \\
Durbin-Watson stat & 2.121339 & & \\
\hline \hline
\end{tabular}

* p-value incompatible with t-Bounds distribution.

ARDL Error Correction Regression

Dependent Variable: D(LNPR)

Selected Model: ARDL $(1,1,1)$

Case 2: Restricted Constant and No Trend

Date: 20/09/20 Time: 09:42

Sample: 2010M01 2019M12

Included observations: 119

\begin{tabular}{|c|c|c|c|c|}
\hline \multicolumn{5}{|c|}{$\begin{array}{c}\text { ECM Regression } \\
\text { Case 2: Restricted Constant and No Trend }\end{array}$} \\
\hline Variable & Coefficient & Std. Error & $\mathrm{t}$-Statistic & Prob. \\
\hline D(LNTD) & -0.086600 & 0.041275 & -2.098119 & 0.0381 \\
\hline D(LNTF) & 0.036124 & 0.033604 & 1.074994 & 0.2847 \\
\hline CointEq $(-1)^{*}$ & -0.002629 & 0.000672 & -3.911902 & 0.0002 \\
\hline R-squared & 0.100743 & Mean dependent var & & -0.003553 \\
\hline Adjusted R-squared & 0.085238 & S.D. dependent var & & 0.013249 \\
\hline S.E. of regression & 0.012672 & Akaike info criterion & & -5.873998 \\
\hline Sum squared resid & 0.018626 & Schwarz criterion & & -5.803936 \\
\hline Log likelihood & 352.5029 & Hannan-Quinn criter. & & -5.845548 \\
\hline Durbin-Watson stat & 0.516116 & & & \\
\hline
\end{tabular}


Ibrahim \& Indra | An Empirical Analysis of Islamic Banking (IBs) Contribution to Indonesia's Inclusive Growth.

\begin{tabular}{|c|c|c|c|c|}
\hline \multicolumn{5}{|c|}{${ }^{*}$-value incompatible with t-Bounds distribution. } \\
\hline \multicolumn{5}{|c|}{ ARDL Error Correction Regression } \\
\hline \multicolumn{5}{|c|}{ Dependent Variable: D(LNUR) } \\
\hline \multicolumn{5}{|c|}{ Selected Model: $\operatorname{ARDL}(3,3,3)$} \\
\hline \multicolumn{5}{|c|}{ Case 2: Restricted Constant and No Trend } \\
\hline \multicolumn{5}{|l|}{ Date: 20/09/20 Time: 09:43 } \\
\hline \multicolumn{5}{|l|}{ Sample: 2010M01 2019M12 } \\
\hline \multicolumn{5}{|l|}{ Included observations: 117} \\
\hline \multicolumn{5}{|c|}{ ECM Regression } \\
\hline \multicolumn{5}{|c|}{ Case 2: Restricted Constant and No Trend } \\
\hline Variable & Coefficient & Std. Error & t-Statistic & Prob. \\
\hline $\mathrm{D}(\mathrm{LNUR}(-1))$ & 0.480326 & 0.087803 & 5.470475 & 0.0000 \\
\hline $\mathrm{D}(\mathrm{LNUR}(-2))$ & 0.212724 & 0.090420 & 2.352609 & 0.0205 \\
\hline $\mathrm{D}(\mathrm{LNTD})$ & -0.046361 & 0.033876 & -1.368541 & 0.1741 \\
\hline $\mathrm{D}(\mathrm{LNTD}(-1))$ & -0.063958 & 0.033437 & -1.912774 & 0.0585 \\
\hline $\mathrm{D}(\operatorname{LNTD}(-2))$ & 0.043412 & 0.032075 & 1.353461 & 0.1788 \\
\hline D(LNTF) & -0.024393 & 0.023808 & -1.024572 & 0.3079 \\
\hline $\mathrm{D}(\operatorname{LNTF}(-1))$ & -0.024828 & 0.026179 & -0.948412 & 0.3451 \\
\hline $\mathrm{D}(\mathrm{LNTF}(-2))$ & -0.019230 & 0.024421 & -0.787420 & 0.4328 \\
\hline CointEq(-1)* & -0.124950 & 0.028241 & -4.424351 & 0.0000 \\
\hline R-squared & 0.449447 & Mean dependent var & & -0.003275 \\
\hline Adjusted R-squared & 0.408666 & S.D. dependent var & & 0.011174 \\
\hline S.E. of regression & 0.008593 & Akaike info criterion & & -6.602014 \\
\hline Sum squared resid & 0.007974 & Schwarz criterion & & -6.389539 \\
\hline Log likelihood & 395.2178 & Hannan-Quinn criter. & & -6.515751 \\
\hline Durbin-Watson stat & 2.058510 & & & \\
\hline \multicolumn{5}{|c|}{ * ${ }^{*}$-value incompatible with t-Bounds distribution. } \\
\hline \multicolumn{5}{|c|}{ ARDL Error Correction Regression } \\
\hline \multicolumn{5}{|c|}{ Dependent Variable: D(LNGR) } \\
\hline \multicolumn{5}{|c|}{ Selected Model: ARDL(3, 3, 3) } \\
\hline \multicolumn{5}{|c|}{ Case 2: Restricted Constant and No Trend } \\
\hline \multicolumn{5}{|c|}{ Date: 20/09/20 Time: 09:43 } \\
\hline \multicolumn{5}{|l|}{ Sample: 2010M01 2019M12 } \\
\hline \multicolumn{5}{|l|}{ Included observations: 117} \\
\hline \multirow{2}{*}{\multicolumn{5}{|c|}{$\begin{array}{c}\text { ECM Regression } \\
\text { Case 2: Restricted Constant and No Trend }\end{array}$}} \\
\hline & & & & \\
\hline Variable & Coefficient & Std. Error & t-Statistic & Prob. \\
\hline D(LNGR(-1)) & 0.788854 & 0.092569 & 8.521804 & 0.0000 \\
\hline $\mathrm{D}(\operatorname{LNGR}(-2))$ & -0.042026 & 0.090267 & -0.465570 & 0.6425 \\
\hline $\mathrm{D}(\mathrm{LNTD})$ & 0.007311 & 0.009301 & 0.785993 & 0.4336 \\
\hline $\mathrm{D}(\operatorname{LNTD}(-1))$ & 0.018934 & 0.009453 & 2.002836 & 0.0478 \\
\hline $\mathrm{D}(\operatorname{LNTD}(-2))$ & -0.001731 & 0.008916 & -0.194201 & 0.8464 \\
\hline $\mathrm{D}(\mathrm{LNTF})$ & 0.005313 & 0.006423 & 0.827129 & 0.4100 \\
\hline $\mathrm{D}(\operatorname{LNTF}(-1))$ & -0.008211 & 0.007286 & -1.127025 & 0.2623 \\
\hline $\mathrm{D}(\operatorname{LNTF}(-2))$ & -0.002998 & 0.006709 & -0.446934 & 0.6558 \\
\hline CointEq(-1)* & -0.044565 & 0.011978 & -3.720750 & 0.0003 \\
\hline R-squared & 0.684603 & Mean dependent var & & $-5.22 \mathrm{E}-05$ \\
\hline Adjusted R-squared & 0.661241 & S.D. dependent var & & 0.004042 \\
\hline S.E. of regression & 0.002352 & Akaike info criterion & & -9.193001 \\
\hline
\end{tabular}


Ibrahim \& Indra | An Empirical Analysis of Islamic Banking (IBs) Contribution to Indonesia's Inclusive Growth.

\begin{tabular}{|llll|}
\hline Sum squared resid & 0.000598 & Schwarz criterion & -8.980526 \\
Log likelihood & 546.7906 & Hannan-Quinn criter. & -9.106739 \\
Durbin-Watson stat & 2.009723 & & \\
\hline \hline
\end{tabular}

International Journal of Islamic Economics and Finance (IJIEF), 4(SI), 87-120| 119 
Ibrahim \& Indra $\mid$ An Empirical Analysis of Islamic Banking (IBs) Contribution to Indonesia's Inclusive Growth.

This page is intentionally left blank.

International Journal of Islamic Economics and Finance (IJIEF), 4(SI), 87-120 120 